Article

\title{
The Possible Stimulation of the Mid-Holocene Period's Initial Hydrological Recession on the Development of Neolithic Cultures along the Margin of the East Asian Summer Monsoon
}

\author{
Wenping Xue ${ }^{1,2}$, Heling Jin ${ }^{1, *}$, Bing Liu ${ }^{1,3, *}$, Liangying Sun ${ }^{1}$ and Zhenyu Liu ${ }^{1}$ \\ 1 Key Laboratory of Desert and Desertification, Cold and Arid Regions Environmental and Engineering \\ Research Institute, Chinese Academy of Sciences, 320 Donggang West Road, Lanzhou 730000, China; \\ xuewenping@lzb.ac.cn (W.X.); sunfly@lzb.ac.cn (L.S.); colorfulblackyuwen@163.com (Z.L.) \\ 2 University of Chinese Academy of Sciences, 19 Yuquan Road, Shijingshan District, Beijing 100049, China \\ 3 Key Laboratory of Western China Environmental System, Lanzhou University, 222 Tianshui South Road, \\ Lanzhou 730000, Gansu, China \\ * Correspondence: jinhl@lzb.ac.cn (H.J.); liubing2014@lzb.ac.cn (B.L.); Tel.: +86-0931-496-7495 (H.J.)
}

Received: 14 August 2019; Accepted: 31 October 2019; Published: 4 November 2019

check for updates

\begin{abstract}
A better understanding of past East Asian summer monsoonal (EASM) variations, which play a key role in the development of the largely rain-watered agriculture in China, could contribute to better appraising potential impacts on EASM with regard to global climate change. However, our knowledge of the relationship between mid-Holocene hydrological recession and the development of Neolithic culture is limited due to a lack of joint studies and a compilation of spatiotemporal data, especially on the episode of $\sim 6-5 \mathrm{ka}$ from the mid-Holocene Optimum (HO) along the peripheral realm of the EASM. Here, we suggest that the hydrological recession between $\sim 6-5 \mathrm{ka}$, on the basis of lithology and geochemical element analysis, occurred not only in the Horqin sandy land, but also in other fluvial-lacustrine, stalagmitic, loess, and aeolian records across the whole monsoon-influenced boundary belt. These records indicated varied, more or less synchronous, and coherent moisture changes, yet with not entirely consistent onsets, durations, and degrees. We attributed this spatiotemporal complexity to the orbit-induced weakening of summer solar insolation, and the interactions of the Asian monsoon (AM) and westerlies, as well as topography and regional vegetation factors. Furthermore, the mid-Holocene initial hydroclimatic recession during $\sim 6-5$ ka within the thresholds of an eco-environment bearing a capacity system, might have facilitated the development of mid-late Neolithic culture and stimulated the north and northwest expansion and integration of region-specific Neolithic culture.
\end{abstract}

Keywords: hydrological recession; mid-Holocene; geochemical elements; EASM margin; Neolithic culture

\section{Introduction}

The Neolithic age usually refers to the emergence of a set of technological innovations and social developments, including the domestication of animals and plants, the practice of settlement, and the use of pottery and ground stone tools [1,2]. Millet, rice, and wheat are the dominant crops in China [3]. Domesticated foxtail millet (Setaria italica) and broomcorn millet (Panicum miliaceum) became widespread by $6000 \mathrm{BC}$ along the Yellow and Liao rivers [4,5]. Technological innovation and settlement were major characteristics in the rise and development of early Neolithic civilizations (7000-5000 BC) [2]. The Neolithic people in different regions of China adopted varied survival strategies 
to cope with the diverse climate and complicated topographical features. In recent decades, numerous joint studies of the link between climatic and societal change have been conducted, especially on during the mid-Holocene (8-3 ka) due to the highly variable climate compared with the preceding and succeeding periods [6,7]. For example, widespread dramatic climatic transition of Holocene event 3 [8-13], HE3 ( 4.2 ka) [14], has been intimately tethered to the collapse of the Harappan civilization [11,15], the domain of the Ancient Egypt [9], and the Akkadian empire [16]. As one of the cradles of ancient civilization, contemporaneous Chinese cultures also experienced the cultural decline and atavism of late-Neolithic cultures at $\sim 4.2 \mathrm{ka}$ in different regions with the exception of Erlitou Culture [17-24]. The decline of culture around $4.2 \mathrm{ka}$ involved a drastic decrease in the number of archaeological sites, the disappearance of large-scale, sophisticated architectures, and the replacement of agricultural civilization by widespread pastoralism in northern semiarid China [25-27].

In comparison with the impact of HE3 on the decline of late-Neolithic culture, the role of climatic degeneration during $\sim 6-5 \mathrm{ka}$ from the Holocene Optimum (HO) is more complex and ambiguous in terms of the development of mid-late Neolithic culture. That is attributed to the following possible reasons: factors based on the spatiotemporal complexity of climatic change, such as not absolutely synchronous timing and various degrees of climatic degeneration, and complicated dynamic mechanisms of cultural evolution, such as the level of socio-economic resilience and the magnitude of capacity-related carrying [28,29].

Previously, multi-proxy records and synthesized data indicated an occurrence of climate deterioration during $\sim 6-5 \mathrm{ka}$ in many regions of the world. This was found not only in Asia [11,30,31], Africa [32], Europe [33-35], and the North Atlantic [14,36], but also in South and North America [37,38], and even in the southern hemisphere [39,40]. Especially in Asia and Africa, the hydrological degradation at 5.5 ka was very prominent [33].

In China, with a temporal resolution of 3-7 years, stalagmite $\delta^{18} \mathrm{O}$ of the Tianmen cave recorded an obvious precipitation anomaly at 6.3 and $5.3 \mathrm{ka}$ in the southern Tibetan Plateau [41]. The $\delta^{18} \mathrm{O}$ record from Dunde ice suggested sharp cooling events during 6.0-5.0 ka [42]. A multi-proxy record from Qixing cave indicated major climate deterioration at 6.5-5.9 ka, followed by water level further dropping and a significant reduction in lake productivity [43], which is identical to the Dahu swamp record [44] and the Dongge stalagmite record [45,46]. However, in Dajiuhu, principal component analysis denoted that a warm and wet condition dominated in 7.0-4.2 ka, with decreased precipitation beginning at $4.2 \mathrm{ka}$ [47]. In northern China, Goldsmith [48,49] proposed a substantial decrease in rainfall at $5.5 \mathrm{ka}$ in Dali lake, in broad agreement with the record from the Chinese Loess Plateau (CLP) [50]. Stalactite data from Wanxiang cave suggested a weakening intensity of the East Asian summer monsoon (EASM) at 5.7-4.9 ka, with an extreme event at 5.4 ka resulting in a significant reduction in precipitation in the western CLP of Gansu [51,52]. The pollen profile from Qinghai Lake demonstrated that $\mathrm{HO}$ vegetation began to shrink at $\sim 6 \mathrm{ka}$, and tree-pollen concentration almost reached the Holocene minimum at $\sim 4.0$ ka [52]. In addition, numerous studies of synthesized data also suggested that effective moisture started to decrease from $6 \mathrm{ka}$, with an abrupt shift at $4.5 \mathrm{ka}$ in northern China [53-57]. Simultaneously, it could be observed that climatic transition was punctuated and superimposed by a series of global cold/dry events $[14,36,58,59]$.

Different from the rise and blossoming of the Mesopotamian civilization and pre-civilization Egypt under gradual climatic decline [60], Wu [61] proposed, on the basis of a large amount of archaeological evidence, that the 6-5 ka climate transition in China caused resource stress and competition increment, and the resultant formation of unequal and complex societies. Bai [51] suggested that the dramatic decline in precipitation at $5.4 \mathrm{ka}$ may have been partly related to the decline of the Miaodigou, middle Yangshao, and early Dawenkou cultures. Previous climatic studies and archaeological surveys provided good opportunities to investigate how prehistoric human activities responded to ecological change and perceived human-nature interactions. However, only a few studies tried to comprehensively explore the relationship between the hydrological recession at $6-5 \mathrm{ka}$ and mid-late Neolithic culture's development [51,61]. Consequently, further work is needed to fully understand 
how climatic degeneration during $\sim 6-5 \mathrm{ka}$ affected the development of mid-late Neolithic culture. Utilizing a compilation of archaeological data by Hosner [62], and combining the earlier paleoclimatic records with our recent research, we were able to delineate spatiotemporal properties of cultural evolution, agricultural development, and subsistence strategies of Neolithic humans, accompanied by paleoclimatic variation during $\sim 6-5 \mathrm{ka}$ along the peripheral realm of the EASM, which had the sensitivity needed for variations of EASM waxing and waning; it was the arena for the rise and fall of pristine civilizations $[18,63]$. Detailed spatiotemporal information about climatic change and the distribution of archaeological sites is important for improving the understanding of the climatic driving mechanism and human responses during the Holocene, and for providing advice for the sustainable development of humans.

\section{Regional Setting}

The peripheral realm of EASM, a broad transitional zone between the influence of Asian monsoon (AM) and westerly-dominated regions, sensitively reflects the spatial expansion or withdrawal of the dominated circulation systems during the Holocene (Figure 1) [53]; this is also a pastoral farming and ecologically fragile zone. Contemporary vegetation across the belt is characterized by ecological diversity, involving ecotones of major biomes between cold-temperate needle-leaf forests and temperate steppes, between temperate steppes and temperature deserts, and between temperature deserts and highland meadows/steppes from the east to the west $[64,65]$.

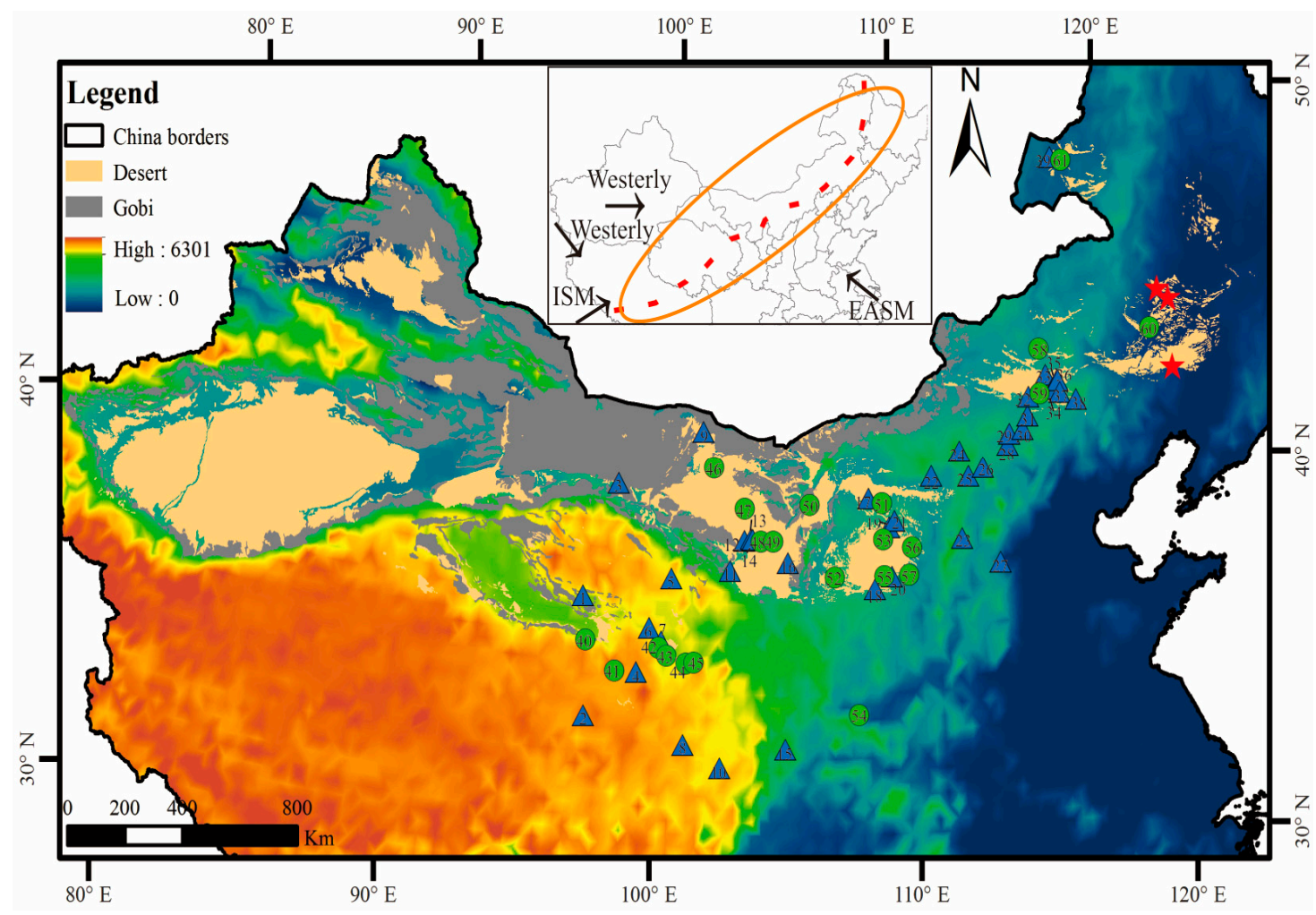

Figure 1. Study area and location of various sites shown in Table 1 to infer mid-Holocene hydrological recession along margin of the East Asian summer monsoon (EASM, red dashed line). Blue triangles represent records of published fluvial-lacustrine and stalagmites with their numbers, and green circles represent the records of published aeolian and loess with their numbers, both of which correspond to the numbers of Table 1. Red stars are the study location. ISM represents the Indian summer monsoon. 
Table 1. Results of optically stimulated luminescence (OSL) dating age and related parameters for Xinjiamu (XJM), Hanxiantun (HXT), and Yangxumu (YXM) profiles.

\begin{tabular}{|c|c|c|c|c|c|c|c|c|}
\hline Lab No. & $\begin{array}{c}\text { Depth } \\
\text { (cm) }\end{array}$ & $\mathrm{U}(\mathrm{ppm})$ & Th (ppm) & K (\%) & $D_{e}(G y)$ & D (Gy/ka) & $\begin{array}{c}\text { Water } \\
\text { Content } \\
(\%)\end{array}$ & Age (ka) \\
\hline XJM-1 & 110 & $0.84 \pm 0.05$ & $3.67 \pm 0.14$ & $2.37 \pm 0.07$ & $7.31 \pm 0.27$ & $3.19 \pm 0.13$ & 5 & $2.3 \pm 0.1$ \\
\hline XJM-2 & 170 & $0.74 \pm 0.04$ & $3.29 \pm 0.13$ & $2.34 \pm 0.07$ & $12.72 \pm 0.30$ & $3.07 \pm 0.12$ & 3.4 & $4.1 \pm 0.2$ \\
\hline XJM-3 & 280 & $0.70 \pm 0.04$ & $3.09 \pm 0.12$ & $2.28 \pm 0.07$ & $13.97 \pm 0.66$ & $2.96 \pm 0.12$ & 5.5 & $4.7 \pm 0.3$ \\
\hline XJM-4 & 350 & $0.72 \pm 0.04$ & $3.38 \pm 0.13$ & $2.25 \pm 0.07$ & $17.40 \pm 1.19$ & $2.96 \pm 0.12$ & 5.0 & $5.9 \pm 0.5$ \\
\hline XJM-5 & 495 & $0.90 \pm 0.05$ & $3.65 \pm 0.14$ & $2.29 \pm 0.07$ & $20.13 \pm 1.25$ & $3.06 \pm 0.12$ & 6.6 & $6.6 \pm 0.5$ \\
\hline HXT-1 & 40 & $0.83 \pm 0.05$ & $3.91 \pm 0.15$ & $2.51 \pm 0.07$ & $16.82 \pm 1.05$ & $3.36 \pm 0.13$ & 3.3 & $5.0 \pm 0.4$ \\
\hline HХT-2 & 150 & $0.85 \pm 0.05$ & $3.88 \pm 0.15$ & $2.45 \pm 0.07$ & $21.88 \pm 1.23$ & $3.28 \pm 0.13$ & 3.4 & $6.7 \pm 0.5$ \\
\hline HXT-3 & 245 & $1.04 \pm 0.05$ & $4.90 \pm 0.18$ & $2.59 \pm 0.07$ & $24.04 \pm 1.29$ & $3.55 \pm 0.14$ & 5.8 & $6.8 \pm 0.5$ \\
\hline HXТ-4 & 340 & $1.12 \pm 0.05$ & $5.38 \pm 0.19$ & $2.50 \pm 0.07$ & $36.60 \pm 0.96$ & $3.52 \pm 0.14$ & 4.9 & $10.3 \pm 0.5$ \\
\hline HXT-5 & 470 & $1.20 \pm 0.06$ & $4.97 \pm 0.18$ & $2.34 \pm 0.07$ & $44.66 \pm 2.69$ & $3.36 \pm 0.13$ & 4.2 & $13.2 \pm 1.0$ \\
\hline HXT-6 & 570 & $1.36 \pm 0.07$ & $5.74 \pm 0.20$ & $2.36 \pm 0.07$ & $47.56 \pm 0.86$ & $3.48 \pm 0.14$ & 5.9 & $13.7 \pm 0.6$ \\
\hline HХT-7 & 665 & $1.24 \pm 0.06$ & $5.15 \pm 0.19$ & $2.47 \pm 0.07$ & $56.80 \pm 2.42$ & $3.48 \pm 0.14$ & 5.4 & $16.3 \pm 1.0$ \\
\hline HXT-8 & 740 & $0.75 \pm 0.05$ & $2.92 \pm 0.12$ & $2.31 \pm 0.07$ & $61.45 \pm 1.86$ & $2.93 \pm 0.12$ & 5.0 & $20.9 \pm 1.1$ \\
\hline YXM-1 & 40 & $0.6 \pm 0.04$ & $2.6 \pm 0.11$ & $2.6 \pm 0.07$ & $1.95 \pm 0.17$ & $3.2 \pm 0.13$ & 5.0 & $0.6 \pm 0.05$ \\
\hline YXM-2 & 100 & $0.6 \pm 0.04$ & $2.9 \pm 0.12$ & $2.4 \pm 0.07$ & $2.36 \pm 0.14$ & $3.1 \pm 0.13$ & 5.0 & $0.7 \pm 0.05$ \\
\hline YXM-3 & 195 & $0.7 \pm 0.05$ & $3.5 \pm 0.14$ & $2.8 \pm 0.07$ & $2.84 \pm 0.17$ & $3.5 \pm 0.14$ & 5.0 & $0.8 \pm 0.06$ \\
\hline YXM-4 & 300 & $0.7 \pm 0.05$ & $3.5 \pm 0.14$ & $2.4 \pm 0.07$ & $5.11 \pm 0.27$ & $3.2 \pm 0.13$ & 5.0 & $1.6 \pm 0.1$ \\
\hline YXM-5 & 380 & $0.7 \pm 0.05$ & $3.5 \pm 0.13$ & $2.4 \pm 0.07$ & $13.7 \pm 0.93$ & $3.2 \pm 0.13$ & 5.0 & $4.3 \pm 0.3$ \\
\hline YXM-6 & 530 & $0.7 \pm 0.05$ & $3.5 \pm 0.14$ & $2.5 \pm 0.07$ & $17.4 \pm 0.50$ & $3.2 \pm 0.13$ & 4.0 & $5.4 \pm 0.3$ \\
\hline YXM-7 & 710 & $0.77 \pm 0.05$ & $4.05 \pm 0.15$ & $2.42 \pm 0.07$ & $56.56 \pm 2.39$ & $3.16 \pm 0.13$ & 5.2 & $17.9 \pm 1.0$ \\
\hline YXM-8 & 760 & $0.86 \pm 0.05$ & $4.67 \pm 0.17$ & $2.44 \pm 0.07$ & $112.4 \pm 4.34$ & $3.27 \pm 0.13$ & 6.3 & $34.4 \pm 1.9$ \\
\hline
\end{tabular}

The Horqin sandy land $\left(42^{\circ} 40^{\prime}-45^{\circ} 15^{\prime} \mathrm{N}, 118^{\circ} 30^{\prime}-124^{\circ} 30^{\prime} \mathrm{E}\right.$; $120-800 \mathrm{~m}$ above sea level) is located in the northeast of the transitional zone (Figure 1) with an area of $21.68 \times 10^{4} \mathrm{~km}^{2}$ [66]. The climate dominated by the Asian Monsoon system is a temperate, semiarid environment. Annual average temperature varies from 3 to $7^{\circ} \mathrm{C}$, and average annual precipitation ranges from $350 \mathrm{~mm}$ to $500 \mathrm{~mm}$, with about $70 \%$ of it being concentrated in summer [66]. The Western Liaohe river incises the region with many tributaries, such as the Xilamulun river in the west, the Laoha and Jiaolai rivers in the south, and the Ulijimulun and Xinkai rivers in the north, with certain scattered lakes and ponds that are attributed to the frequent migration or diversion of paleo-channels [67]. The landform is predominated by fixed and semi-fixed dunes [66].

\section{Material and Methods}

\subsection{Optically Stimulated Luminescence (OSL) Dating}

OSL samples were collected from freshly cleaned excavated sections by hammering aluminum tubes into the exposure, and then sealing them with black plastic bags to avoid light exposure and moisture loss, in accordance with Zhao's protocol [68]. Samples were analyzed by the Institute of Hydrogeology and Environmental Geology, Chinese Academy of Geological Sciences. The OSL samples were extracted under subdued red light; then, separated by wet sieving with a 180-mesh sieve. The fine fraction $(4-11 \mu \mathrm{m})$ of quartz grain was extracted according to Stokes' Law. The $4-11 \mu \mathrm{m}$ fraction was handled with $\mathrm{H}_{2} \mathrm{O}_{2}(40 \%)$ and $\mathrm{HCL}(30 \%)$ to remove organic material and carbonate, and then etched with $15 \% \mathrm{H}_{2} \mathrm{SiF}_{6}$ for 5 days to obtain the fine-grained quartz component. All samples were deposited on stainless-steel discs, and then dried at $40{ }^{\circ} \mathrm{C}$ in an oven prior to De measurement. All sample measurements were performed on an automated Daybreak 2200 OSL reader, which was equipped with a combined blue $(470 \pm 5 \mathrm{~nm})$ and infrared $(880 \pm 80 \mathrm{~nm})$ LED OSL unit, and a ${ }^{90} \mathrm{Sr} /{ }^{90} \mathrm{Y}$ beta source (dose rate $0.06 \mathrm{~Gy} / \mathrm{s}$ ). Luminescence emissions were detected by an EMI 9235QA photomultiplier tube and a $3 \mathrm{~mm}$ U-340 filter. The samples' equivalent doses (De) were measured using a sensitivity-corrected multiple aliquot regeneration (SMAR) protocol [69,70]. Subsequently, calculating the dose rates from the concentration of $\mathrm{U}$, Th, and $\mathrm{K}$ was performed by neutron activation 
analysis (NAA). For the fine-grained fraction $(4-11 \mu \mathrm{m})$, the alpha-efficiency value was taken as $0.035 \pm 0.003$ [71]. Cosmic dose rate was calculated from present day burial depth [72]. The water content sample was poured into a beaker to get the wet weight, and then dried at a low temperature in the oven. Finally, the dry weight and the breaker weight were measured, and the water content was calculated [73]. All OSL results are presented in Table 1.

\subsection{Measurements of Geochemical Elements in the Horqin Sandy Land}

A total of 405 samples were collected at $2-5 \mathrm{~cm}$ intervals from top to bottom in the XJM, HXT, and YXM sections, and 157 samples were measured for geochemical elements: 50 samples from XJM, 31 samples from HXT, and 76 samples from YXM. All measurements of the geochemical elements were performed in the Key Laboratory of Desert and Desertification, Cold and Arid Regions, Environmental and Engineering Research Institute, Chinese Academy of Sciences. The procedures were as follows: First, samples were dried, ground, and sifted through a 200-mesh screen. Then, $4 \mathrm{~g}$ of powdered samples were pressed into round discs of $32 \mathrm{~mm}$ diameters with boric acid at the edges and bottoms under 30-ton pressure and at $105^{\circ} \mathrm{C}$. Finally, the discs were measured with the spectrometer using a super-long, sharp-pointed ceramic X-ray light tube $(4.0 \mathrm{~kW}, 60 \mathrm{kV}, 160 \mathrm{~mA}, 75 \mu$ UHT Be end window). The estimated error of major elements was less than $5 \%$, and for the trace elements it was less than 25\% according to GB/T14506 28-93 (Silicate rocks: Determination of contents of major and minor elements-X-ray fluorescence spectrometric methods).

\subsection{Holocene Lacustrine, Stalagmite, Loess, and Aeolian Records from the EASM Boundary}

In order to investigate overall Holocene hydrological changes, we compared hydrographic recession with a synthesis of published paleoclimate records from 39 paleolake sections and peat sections, two stalagmite sections, and 22 aeolian (loess) records along the peripheral realm of the EASM. All sections are listed in Table 2.

\subsection{The Munsell Soil Color Charts}

Soil color was measured using the Munsell soil color charts [74]. The measurement of color was repeated twice with two different persons performing the visual measurements. Based on chroma and value, all measurement samples were found to belong the one Hue group; namely, 10YR.

\section{Results}

\subsection{Chronology and Stratigraphy}

The XJM, HXT, and YXM sections are located in the northern, central northern, and southern portion of Horqin sand land (Figure 1). Stratigraphy sequences are described in Figure 2. The XJM section consists of two units, aeolian sand $(500-350 \mathrm{~cm}, 170-135 \mathrm{~cm}, 100-20 \mathrm{~cm})$ and sandy paleosols (350-170 cm, 135-100 cm). In the XJM section, the aeolian sands $(500-350 \mathrm{~cm}, 100-20 \mathrm{~cm})$ are grayish yellow-brown (10YR 6/2) or brownish-gray (10YR 6/1); the two layers of paleosols are light gray (10YR $7 / 1$ ) or brownish-gray (10YR 5/1), and generally developed discontinuously in spatial distribution because of the horizontal annihilation of the middle layer of aeolian sand observed on the field survey. The ages of the bottom sands are at $6.6 \pm 0.5 \mathrm{ka}$ and $5.9 \pm 0.5 \mathrm{ka}$ in the lower and top boundaries, respectively. The HXT section consists of aeolian sand $(750-665 \mathrm{~cm}, 160-10 \mathrm{~cm})$, sandy loess $(665-470 \mathrm{~cm})$, and sandy paleosols $(470-160 \mathrm{~cm})$. In the HXT section, the upper aeolian sands are brownish-gray (10YR 6/1), poor to medium sorted; the sandy paleosol is grayish-brown (10YR 5/2); the sandy loess is grayish-brown (10YR 6/2); the bottom sand is grayish-yellow (10YR 6/2), well-sorted, and exhibiting obvious differences with the upper sand, all of whose deposited ages were $6.7-5.0 \mathrm{ka}$ ago. The YXM section, located in the Valley of Yangxumu River, is composed of the lower portion of fluvial-lacustrine facies $(760-600 \mathrm{~cm})$ that were deposited between the last glacial and early Holocene, and an upper portion $(600-10 \mathrm{~cm})$ of aeolian sedimentary facies since the middle Holocene. During 
field research, we found that the upper and lower sedimentary facies presented an obviously angular unconformity contact, with the top age of the aeolian sand at $5.4 \pm 0.3 \mathrm{ka}$ at the transition site of the sedimentary facies.

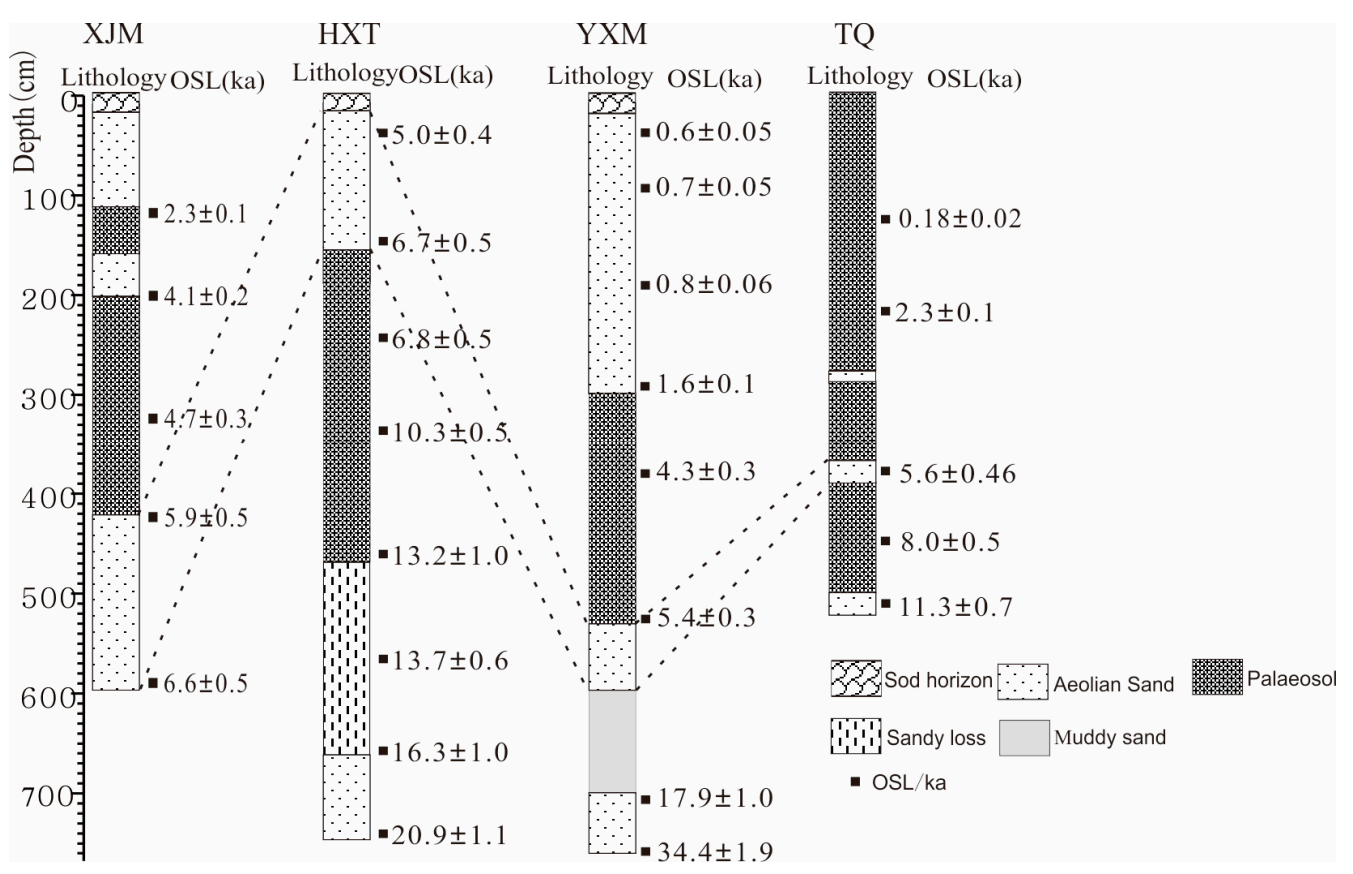

Figure 2. The aeolian-paleosols sequences in the Horqin sandy land. The TQ section was provided by Guo [75]. 
Table 2. Non-exhaustive list for fluvial-lacustrine, stalagmitic, loess, and aeolian records of mid-Holocene climatic change along the EASM margin. Site locations shown in Figure 1.

\begin{tabular}{|c|c|c|c|c|c|c|c|c|c|}
\hline No. site & Latitude & Longitude & Elevation & Archive & Proxy & $\begin{array}{c}\text { Climate } \\
\text { Signal }\end{array}$ & Onset Age (cal.kyr BP) & Dating Method & Reference \\
\hline 1. Hurleg Lake & 37.28 & 96.9 & 2817 & Lake & $\mathrm{OM}, \mathrm{Ca}, \mathrm{MS}, \mathrm{GE}, 818 \mathrm{O}$, & dry & $6.2-5.9,5.3-4.9$ & $\mathrm{AMS}^{14} \mathrm{C}$ & [76] \\
\hline 2. Koucha Lake & 34.01 & 97.24 & 4530 & Lake & P, GE, TOC, $\delta 13 \mathrm{C}, \delta 18 \mathrm{O}$ & dry & 4.3 & ${ }^{14} \mathrm{C}$ & [77] \\
\hline 3. Huahai & 40.43 & 98.07 & 1200 & Lake & $\mathrm{GS}, \mathrm{Ca}, \mathrm{TOC}, \mathrm{C} / \mathrm{N}$ & dry & 5.5 & $\mathrm{AMS}^{14} \mathrm{C}$ & [78] \\
\hline 4. Kuhai Lake & 35.30 & 99.18 & 4150 & Lake & LOI, GS, $\delta 13 \mathrm{C}, \delta 18 \mathrm{O}, \mathrm{P}, \mathrm{GE}$ & dry & $6.1-5.4$ & ${ }^{14} \mathrm{C}$ & [79] \\
\hline 5. Qinghai Lake & 37.91 & 99.6 & 3200 & Lake & $\mathrm{P}, \mathrm{Ca}, \mathrm{TOC}, \mathrm{TN}, \delta 13 \mathrm{C}$ & dry & $6-4.5$ & $\mathrm{AMS}^{14} \mathrm{C}$ & [52] \\
\hline 6. Genggahai & 36.18 & 100.1 & 2860 & Lake & $\mathrm{GE}, \mathrm{FO}, \mathrm{TOC}, \mathrm{TN}, 813 \mathrm{C}$, & dry & $6.3-5.5$ & ${ }^{14} \mathrm{C}$ & [80] \\
\hline 7. Dalianhai & 36.53 & 100.4 & 2850 & Lake & $\mathrm{Ca}, \mathrm{GS}, \mathrm{P}$ & dry & $5.7-3.9$ & $\mathrm{AMS}^{14} \mathrm{C}$ & [81] \\
\hline 8. Ximencuo Lake & 33.38 & 101.1 & 4030 & Lake & $\mathrm{TOC}^{13} \mathrm{C}, \mathrm{C} / \mathrm{N}, \mathrm{GS}, \mathrm{MS}$ & cold & $5.7,4.2$ & ${ }^{14} \mathrm{C}$ & [82] \\
\hline 9. Juyanze Lake & 41.99 & 101.53 & 920 & Lake & $\mathrm{P}, \mathrm{L}$ & dry & $7-5$ & $\mathrm{AMS}^{14} \mathrm{C}$ & [83] \\
\hline 10. Hongyuan Peatland & 32.78 & 102.51 & 3527 & Outcrop & St, $P$ & cold, dry & $6.2,5.9-4.1$ & ${ }^{14} \mathrm{C}$ & [84] \\
\hline 11. Hongshui River & 38.18 & 102.76 & 1460 & Outcrop & $\mathrm{GE}, \delta^{13} \mathrm{C}, \delta 18 \mathrm{O}, \mathrm{P}$ & dry, warm & 6.2-5.6, 5.0-4.4, & ${ }^{14} \mathrm{C}$ & {$[85,86]$} \\
\hline 12. Zhuyeze (Sanjiaocheng) & 39.01 & 103.34 & 1320 & Lake & L, P, LOI & dry & $7-5$ & $\mathrm{AMS}^{14} \mathrm{C}$ & [87] \\
\hline 13. Qingtu Lake & 39.07 & 103.61 & 1302 & Outcrop & $\mathrm{MS}, \mathrm{GS}, \mathrm{Ca}, \mathrm{P}$ & dry & 4.7 & $\mathrm{AMS}^{14} \mathrm{C}$ & [88] \\
\hline 14. Zhuyeze & 39.05 & 103.67 & 1309 & Outcrop & GS, P, GE, & dry & 4.7 & $\mathrm{AMS}^{14} \mathrm{C}$ & [89] \\
\hline 15. Wanxiang Cave & 33.32 & 105 & 1200 & Stalagmites & $\delta^{18} \mathrm{O}$ & dry & $6.1-5.7,5.7-4.9$ & ${ }^{230} \mathrm{Th}$ & [51] \\
\hline 16. Toudaohu Lake & 38.42 & 105.12 & 1300 & Lake & $\mathrm{P}, \mathrm{L}$ & dry & $7-5$ & $\mathrm{AMS}^{14} \mathrm{C}$ & [83] \\
\hline 17. Yanhaizi & 40.13 & 108.45 & 1180 & Lake & GS, TOC, TOC/TN, MS & dry & $5.8-4.3$ & $\mathrm{AMS}^{14} \mathrm{C}$ & [90] \\
\hline 18. Midiwan & 37.65 & 108.62 & 1400 & Peat secton & $\mathrm{P}, \mathrm{TOC}, \delta 13 \mathrm{C}$ & dry, warm & $7.5-4.5$ & $\mathrm{AMS}^{14} \mathrm{C}$ & [91] \\
\hline 19. Baihar Nuur & 39.32 & 109.27 & 1278 & Lake & $\mathrm{P}, \mathrm{L}, \mathrm{Ca}, \mathrm{TOC}, \delta 13 \mathrm{C}$ & humid & $6.3-4.4$ & $\mathrm{AMS}^{14} \mathrm{C}$ & [92] \\
\hline 20. Bojianghaizi Lake & 37.97 & 109.31 & 1365 & Lake & GS, LOI, P & dry & 6.8 & $\mathrm{AMS}^{14} \mathrm{C}$ & [93] \\
\hline 21. QigaiNuur & 39.5 & 109.5 & 1403 & Lake & $\mathrm{P}, \mathrm{GE}, \mathrm{OM}$ & cold, dry & 7.4-6 & $\mathrm{AMS}^{14} \mathrm{C}$ & [94] \\
\hline 22. Qasq Peat & 40.67 & 111.12 & 1000 & Outcrop & $\mathrm{P}$ & dry & $4100-2400\left({ }^{14} \mathrm{C}\right)$ & ${ }^{14} \mathrm{C}$ & [95] \\
\hline 23. Gonghai lake & 38.9 & 112.23 & 1860 & Lake & $\mathrm{Ca}, \mathrm{EM}, \mathrm{GC}, \mathrm{GS}, \mathrm{OM}, \mathrm{P}$ & warm, dry & $5.5-4.8$ & $\mathrm{AMS}^{14} \mathrm{C}$ & {$[96,97]$} \\
\hline 24. Diaojiaohaizi Lake & 41.3 & 112.35 & 1800 & Lake & $\mathrm{P}$, & warm, dry & $4400-3000\left({ }^{14} \mathrm{C}\right)$ & ${ }^{14} \mathrm{C}$ & [98] \\
\hline 25. Daihai Lake & 40.59 & 112.67 & 1230 & Lake & P, Ma. & dry & $6,4.5-2.9$ & $\mathrm{AMS}^{14} \mathrm{C}$ & [99-101] \\
\hline 26. Huangqihai & 40.8 & 113.3 & 1277 & Lake & GS, GE, MS & cold, dry & $6.7-5.5,5.0-4.0$ & $\mathrm{AMS}^{14} \mathrm{C}, \mathrm{OSL}$ & [102] \\
\hline 27. Lianhua Cave & 38.17 & 113.72 & 1200 & Stalagmites & $\delta^{18} \mathrm{O}$ & dry & 6.5 & ${ }^{230} \mathrm{Th}$ & [103] \\
\hline 28. AnguliNuur Lake & 41.35 & 114.4 & 1315 & Lake & MS, GS, P, TOC, C/N & dry & $6.3-3.5$ & $\mathrm{AMS}^{14} \mathrm{C}^{210} \mathrm{~Pb} /{ }^{137} \mathrm{Cs}$ & {$[104,105]$} \\
\hline 29. BaiNuur & 41.64 & 114.52 & 1346 & Outcrop & MS, GS, $\mathrm{P}$ & dry & $6.9 / 6.8$ & $\mathrm{AMS}^{14} \mathrm{C}$ & {$[105,106]$} \\
\hline 30. UlanNuur & 41.74 & 115.09 & 1246 & Outcrop & MS, GS, P, TOC, C/N & dry & $6.2 / 6.1$ & $\mathrm{AMS}^{14} \mathrm{C}$ & {$[105,106]$} \\
\hline 31. Bayanchagan Lake & 42.08 & 115.35 & 1355 & Lake & Pollen & dry & $6.5-5.1$ & $\mathrm{AMS}^{14} \mathrm{C}$ & [107] \\
\hline 32. Xiarinur & 42.6 & 115.47 & 1225 & Lake & EM, GS, P & dry & 4.9 & $\mathrm{AMS}^{14} \mathrm{C}$ & {$[108]$} \\
\hline 33. Dali Lake & 43.15 & 116.29 & 1220 & Lake & $\mathrm{GE}, \delta^{13} \mathrm{C}, \delta^{18} \mathrm{O}, \delta^{5} \mathrm{~N}$ & dry & $5.9-4.8$ & $\mathrm{AMS}^{14} \mathrm{C}, \mathrm{OSL}$ & [109-111] \\
\hline 34. Liuzhouwan & 42.71 & 116.67 & 1365 & Outcrop & GE, EM, GC, GS, LOI, OM, P & dry & $4700\left({ }^{14} \mathrm{C}\right)$ & $\mathrm{AMS}^{14} \mathrm{C}$ & [112] \\
\hline 35. Haoluku & 42.96 & 116.75 & 1295 & Outcrop & LOI, TOC, GE, MS & dry & $5600\left({ }^{14} \mathrm{C}\right)$ & $\mathrm{AMS}^{14} \mathrm{C}$ & [112] \\
\hline 36. Haolainure & 42.95 & 116.79 & 1295 & outcrop & $\mathrm{P}$ & warm, wet & $5.8-2.9$ & $\mathrm{AMS}^{14} \mathrm{C}, \mathrm{OSL}$ & [113] \\
\hline 37. Xiaoniuchang & 42.62 & 116.83 & 1460 & Outcrop & LOI, TOC, GE, MS, P & dry & $5600-3000\left({ }^{14} \mathrm{C}\right)$ & $\mathrm{AMS}^{14} \mathrm{C}$ & [114] \\
\hline 38. Jiangiunpaozi & 42.37 & 117.47 & 1490 & Outcrop & LOI, TOC, GE, MS, P & dry & $6600-4300\left({ }^{14} \mathrm{C}\right)$ & $\mathrm{AMS}^{14} \mathrm{C}$ & [114] \\
\hline 39. Hulun Lake & 49.13 & 117.51 & 545 & Lake & P & dry & $6.4-4.4$ & $\mathrm{AMS}^{14} \mathrm{C}$ & [115] \\
\hline 40. Tiekui Desert & 36.08 & 97.12 & $2800-3300$ & Aeolian & $\mathrm{L}$ & dry & 4.5 & OSL & [116] \\
\hline
\end{tabular}


Table 2. Cont.

\begin{tabular}{|c|c|c|c|c|c|c|c|c|c|}
\hline No. site & Latitude & Longitude & Elevation & Archive & Proxy & $\begin{array}{c}\text { Climate } \\
\text { Signal }\end{array}$ & Onset Age (cal.kyr BP) & Dating Method & Reference \\
\hline 41. Donggi Cona & 35.3 & 98.32 & 4090 & Aeolian & GS & dry & 6 & $\mathrm{AMS}^{14} \mathrm{C}$ & [117] \\
\hline 42. Gonghe Basin & $35.5-36.93$ & 98.8-101.4 & $2400-3200$ & Aeolian & L, GS, GE & dry & 5 & OSL & [118] \\
\hline 43. Gonghe basin (LG) & 35.80 & 100.33 & 3780 & Aeolian & MS, TOC, $\mathrm{Ca}$, GS, GE & cold, dry & $5.3-4.7$ & OSL & [119] \\
\hline 44. Gonghe basin (DQ) & 35.60 & 101.08 & 3534 & Aeolian & MS, TOC, Ca, GE & dry & $6.5-5.8$ & ${ }^{14} \mathrm{C}$ & [120] \\
\hline 45. Gonghe basin (KE) & 35.65 & 101.1 & 3780 & Aeolian & MS, TOC, $\mathrm{P}$ & cold, dry & $5.3-4.9$ & ${ }^{14} \mathrm{C}$ & [121] \\
\hline 46. Badain(a) & $39.3-42$ & $99.8-104.2$ & $1200-1700$ & Aeolian, Lake & GE & dry & 5 & $\mathrm{AMS}^{14} \mathrm{C}, \mathrm{TL}$ & [122] \\
\hline 47. Badain (b) & $38-40.5$ & $102.5-106.5$ & 1600 & Aeolian & $\mathrm{L}$ & dry & $6-5$ & OSL & [123] \\
\hline 48. Badain (Chagelebuuulu) & 39.89 & 103.30 & 1800 & Aeolian & GE & cold, dry & 6.2 & $\mathrm{AMS}^{14} \mathrm{C}$ & [124] \\
\hline 49. Tengger & $37.45-40$ & $102.2-105.2$ & $1200-1400$ & Aeolian & GS, S & dry & 6 & $\mathrm{AMS}^{14} \mathrm{C}$ & [125] \\
\hline 50. Ulan Buh & $39.8-40.6$ & $105.7-106.5$ & 1030 & Aeolian, Lake & GS & dry & 6.5 & OSL, ${ }^{14} \mathrm{C}$ & [126] \\
\hline 51. Hobq & $39.6-40.8$ & $107.1-111.5$ & 1200 & Aeolian & GS, MS, TOC, TC, Ca, & dry & $7-4$ & OSL & {$[127,128]$} \\
\hline 52. InnerMong (KB, JJ, TYG) & $37.37-40.8$ & $106.1-111.5$ & $1000-1200$ & Aeolian & P & dry & 5.6 & OSL & [129] \\
\hline 53. CLP & $33.68-41.27$ & $100.8-114.5$ & 1000-2000 & Loess & $\mathrm{L}, \mathrm{S}$ & dry & 5.5 & $\mathrm{OSL}_{1}^{14} \mathrm{C}$ & [50] \\
\hline 54. Qingquicun & 34.22 & 107.83 & 500 & Loess & L, GS, GE, MS, TOC & dry & $6-5$ & ${ }^{14} \mathrm{C}$ & [130] \\
\hline 55. MuUs & $37.27-39.22$ & $107.2-111.30$ & $1200-1600$ & Aeolian & L & dry & 5 & OSL & [131] \\
\hline 56. MuUs (JJ) & 38.74 & 110.17 & 1159 & Aeolian & GE & dry & $6.6-5.4$ & OSL & [132] \\
\hline 57. MuUs & $37.45-39.48$ & $107.3-111.5$ & $1000-1200$ & Aeolian & L, TOC, S & dry & 6.4 & ${ }^{14} \mathrm{C}$, OSL & [133] \\
\hline 58. Otindag (HSDK) & 42.66 & 115.95 & 1100 & Aeolian & L, MS, GS, S & dry & 5 & OSL & [134] \\
\hline 59. Otindag (Xilinhot) & 43.88 & 116.093 & 960 & Aeolian & MS, OM & dry & 5.9 & ${ }^{14} \mathrm{C}$ & [135] \\
\hline 60. Horqin & $42.67-45.25$ & $118.5-124.5$ & $120-800$ & Aeolian & $\mathrm{L}, \delta^{13} \mathrm{C}, \mathrm{S}$ & dry & $6-4$ & OSL & {$[57,74]$} \\
\hline 61. Hulunbuir Dune & $47.5-49.5$ & $117.5-119.5$ & $600-800$ & Aeolian & GS, MS, S & dry & 5 & OSL & [136] \\
\hline
\end{tabular}

Grain size—GS, geochemical elements—GE, magnetic susceptibility—MS, organic matter-OM, total carbon—TC, total organic carbon-TOC, carbonate-Ca, pollen—P, macrofossils—FO,

lithology $-\mathrm{L}$, mathematic method-Ma, synthesizing chronological data-S. 


\subsection{Arid Reconstruction and Rb/Sr Ratio}

In Northern China, under dry climate conditions, $\mathrm{K}, \mathrm{Na}, \mathrm{Ca}$, and $\mathrm{Mg}$ are concentrated, while under relatively wet conditions, sediments are rich in Fe and Mn $[119,137]$. Thus, the ratio of elements $(\mathrm{Re})$, expressed by a ratio of $(\mathrm{K}+\mathrm{Na}+\mathrm{Ca}+\mathrm{Mg})$ to $(\mathrm{Fe}+\mathrm{Mn})$, was proposed to evaluate the regional drought and humidity degrees, which increase when the climate becomes drier and vice versa. The value of Re is higher in aeolian sand than in paleosols (Table 3), indicating relatively arid climate (Figure 3).

Table 3. Statistical analysis of geochemical-element contents and ratios in different sections and lithologies.

\begin{tabular}{cccccccc}
\hline Section & Age (ka) & Lithology & $\mathbf{R e}$ & $\mathbf{R b} / \mathbf{S r}$ ratio & $\mathbf{R b}$ (ppm) & $\mathbf{S r}(\mathbf{p p m})$ & $\mathbf{C a C O}_{3}$ \\
\hline \multirow{4}{*}{ XJM } & $6.6-5.9$ & Aeolian sand & 6.06 & 0.725 & 93.5 & 129.6 & 0.44 \\
& $5.9-4.1$ & Paleosol & 5.83 & 0.739 & 95.2 & 128.9 & 0.37 \\
& $4.1-?$ & Aeolian sand & 5.96 & 0.762 & 93.3 & 122.6 & 0.35 \\
& $?-2.3$ & Paleosol & 4.94 & 0.753 & 96.8 & 128.5 & 0.93 \\
& $<2.3$ & Aeolian sand & 5.36 & 0.754 & 93.5 & 124.1 & 1.10 \\
\hline \multirow{3}{*}{ HXT } & $20.9-16.3$ & Aeolian sand & 5.0 & 0.623 & 99.4 & 160.7 & 1.45 \\
& $16.3-13.2$ & Sandy loess & 4.19 & 0.571 & 106.9 & 187.9 & 2.54 \\
& $13.2-6.7$ & Paleosol & 4.50 & 0.498 & 109.5 & 221.0 & 2.99 \\
& $6.7-5.0$ & Aeolian sand & 6.12 & 0.491 & 105.3 & 208.2 & 3.71 \\
\hline \multirow{4}{*}{ YXM } & $34.4-17.9$ & River sand & 4.99 & 0.558 & 101.5 & 182.0 & 0.39 \\
& $17.9-?$ & Muddy sand & 4.75 & 0.557 & 102.7 & 184.7 & 0.61 \\
& $?-5.4$ & Aeolian sand & 5.58 & 0.585 & 102.1 & 174.6 & 0.60 \\
& $5.4-1.6$ & Paleosol & 5.1 & 0.575 & 101.5 & 176.6 & 0.67 \\
\end{tabular}
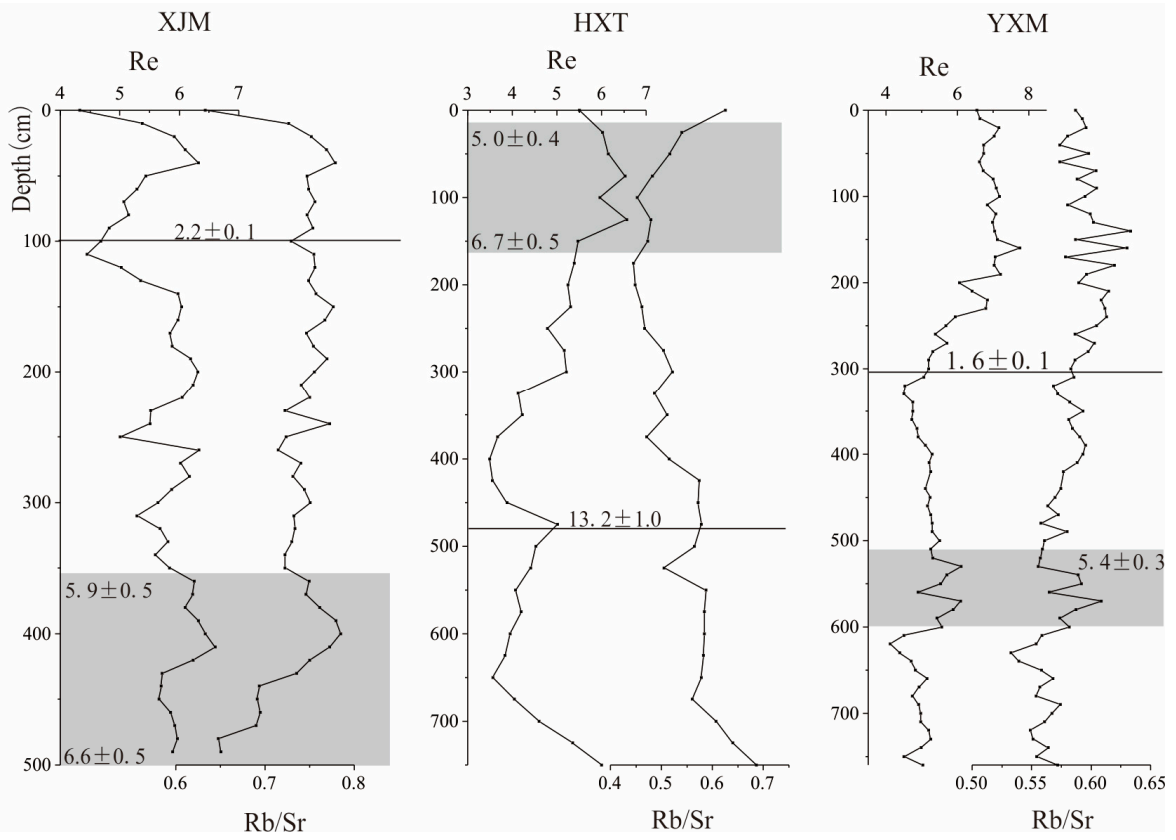

Figure 3. Time series of the moisture change revealed by $\mathrm{Re}$ and $\mathrm{Rb} / \mathrm{Sr}$ ratio in the Horqin sandy land. 
Rubidium $(\mathrm{Rb})$ and strontium $(\mathrm{Sr})$ are easily fractionated in the process of chemical weathering due to their discrepant geochemical behavior [138]. Rb mainly disperses in potassium (K)-containing minerals, such as potassium feldspar, mica, and so on, while Sr usually exists in Ca-containing minerals of plagioclase feldspar, hornblende, crystal, and carbonate. The ratio of $\mathrm{Rb} / \mathrm{Sr}$ in weathered clay minerals is relatively high in response to the preferential accommodation of $\mathrm{Rb}$ adsorbed by $\mathrm{K}$-containing sites and rapid leaching of Sr [139]. Chen [140] suggested that Rb was stable and Sr easily passed into solution. Hence, the $\mathrm{Rb} / \mathrm{Sr}$ ratio significantly increases with the enhancement of weathering intensity in northwestern, relatively arid aeolian sand profiles and loess-paleosol sequences [140,141]. However, in eastern China, especially in Horqin with semi-arid climatic conditions and several tributaries of the Western Liaohe crossing through it, the variation of $\mathrm{Rb} / \mathrm{Sr}$ ratio was not entirely synchronized due to small-scale different physicochemical weathering conditions. It was not noticeable whether the $\mathrm{Rb}$ was relatively enriched or leached; the content of Rb was both low and relatively stable (Figure 4), while the Sr was leached and migrated in the paleosol in comparison with the underlying aeolian sand with a migration ratio of $-3.1 \%$ in the XJM section, and relatively enriched and deposited in the HXT and YXM sections, with deposition ratios of $16.4 \%$ and $0.6 \%$, respectively. This showed consistent geochemical behavior with $\mathrm{Ca}$ in the weathering process of the three sections (Figure 4). Pioneering studies suggested that calcium carbonate would be leached or deposited with various degrees of leaching [142]. In general, abundant precipitation would result in large quantities of carbonate leaching in paleosols; therefore, the low carbonate content in the paleosols indicated a relatively humid climate condition. In Horqin sandy land, on the other hand, even in the loamy stage, $\mathrm{CaCO} 3$ did not move out of the paleosol layers due to relatively low precipitation, leading to the deposition of carbonate and increased contents of carbonate in the paleosols, which implied a variation of precipitation in the pedogenesis and multistage soil formation [143,144]. According to Zhao [143], $\mathrm{CaCO}_{3}$ in paleosols appeared in the form of film, spots, and mycelia when annual average precipitation (Pa) was less than $400 \mathrm{~mm}$, while CaCO3 nodules appeared in paleosols when Pa was more than $400 \mathrm{~mm}$. During the field survey, we found markedly white mycelium and $\mathrm{CaCO}_{3}$ nucleation in the paleosols $(470-160 \mathrm{~cm})$ of the HXT section. Continuous $\mathrm{CaCO}_{3}$ deposition indicated that the amount of precipitation during the soil-forming process was not enough to make $\mathrm{CaCO}_{3}$ leach $[143,144]$. In the YXM section, the paleosols (530-305 cm) contain white mycelium and yellow rust spots, sandwiched with lenticle grayish-yellow, fine sand, sorted well, which might be affected by running water, leading to the relatively high content of $\mathrm{CaCO}_{3}$ in the paleosols. The $\mathrm{Rb} / \mathrm{Sr}$ ratio was mainly dependent on the change of Sr content (Figure 5), which also has consistent geochemical behavior with $\mathrm{Ca}$, leading to $\mathrm{Sr}$ being deposited in the paleosols (Figure 4). Therefore, it was reasonable that the relatively low $\mathrm{Rb} / \mathrm{Sr}$ ratio in the paleosols indicated a relatively humid condition compared with the high content of the $\mathrm{Rb} / \mathrm{Sr}$ ratio with a relatively arid climatic condition in the HXT section. It was the same in the YXM section: the low content of $\mathrm{Rb} / \mathrm{Sr}$ ratio in paleosols indicated the inadequate precipitation in pedogenesis. However, in the XJM section, the high content of $\mathrm{Rb} / \mathrm{Sr}$ ratio in paleosols $(350-170 \mathrm{~cm}$ ) indicated a relatively humid condition resulting from the deep leaching of abounding precipitation during the mid-Holocene. 


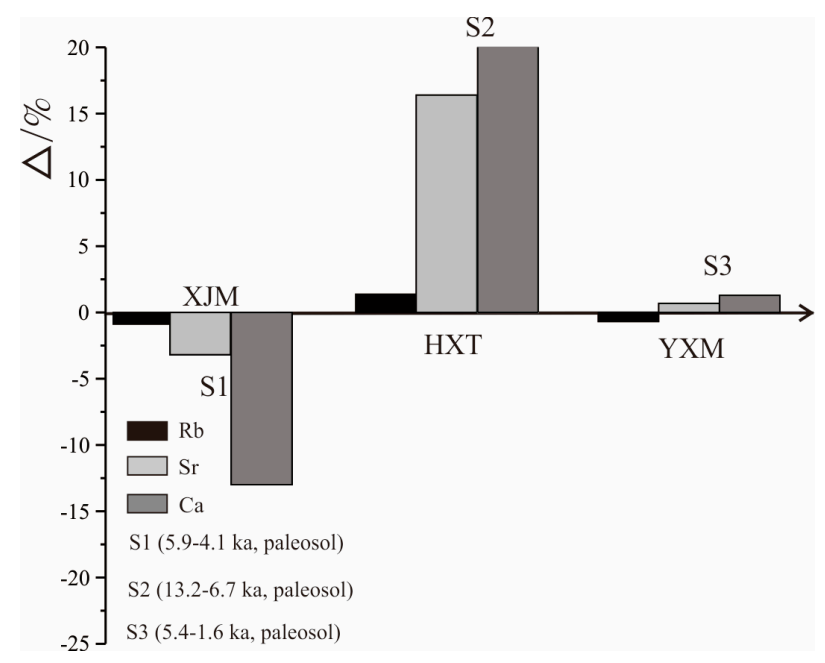

Figure 4. The averag percentage change of $\mathrm{Rb}, \mathrm{Sr}$, and $\mathrm{Ca}$ in the XJM, HXT, and YXM sections in the Horqin sandy land.
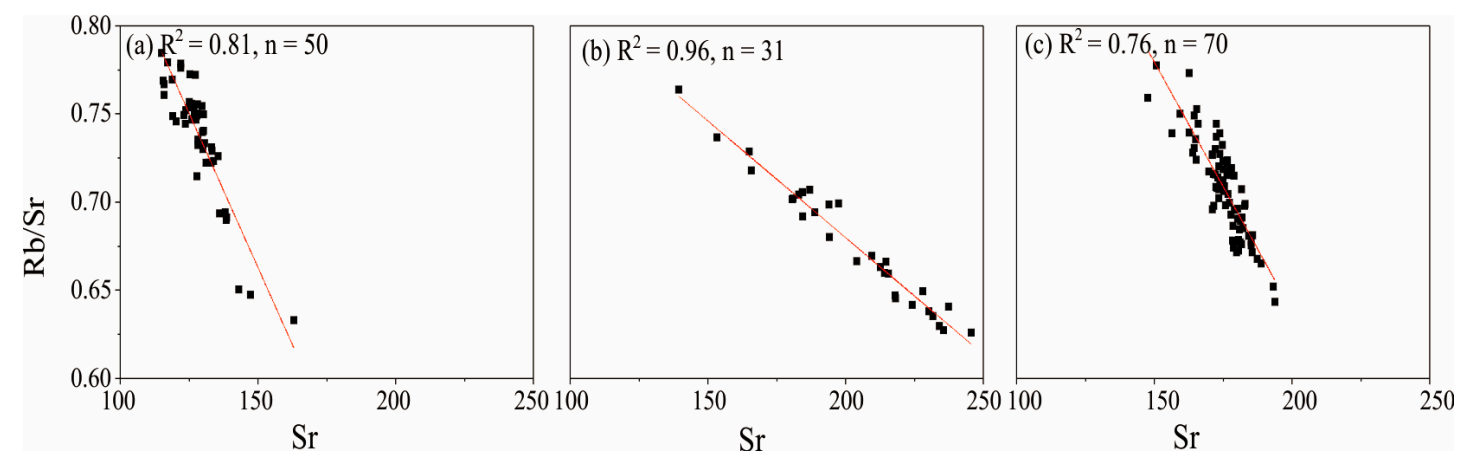

Figure 5. The relationship of $\mathrm{Rb} / \mathrm{Sr}$ ratio and $\mathrm{Sr}$ content in the Horqin sand land. (a) XJM (b) HXT (c) YXM.

\subsection{Holocene Hydrological Changes Indicated by Fluvial-Lacustrine and Aeolian Records}

The Holocene-synthesized arid-humid fluctuation from the published documents of lacustrine, stalagmite, loess, and aeolian sections are partly summarized in Figure 6. Clearly, most fluvial-lacustrine records broadly exhibited that the hydrological environment began to gradually increase in the early Holocene [145], reached optimum humidity conditions during the early-mid Holocene, and then commenced recession after a maximum period at $\sim 6 \mathrm{ka}$, although not entirely consistent with the onset of hydrological recession. The hydroclimatic change of the aeolian deposits at the northwest EASM fringe demonstrated a consistent trend with the fluvial-lacustrine indicator. In comparison, the Holocene hydrological evolution of aeolian records on the northwest part exhibited relatively less effective moisture during the early-mid Holocene and more during late Holocene, such as in Gonghe basin and Qinghai Lake $[119,146]$, which is probably attributed to the non-linear response of aeolian deposits to climate change and multiple factors of aeolian activities [118]. 

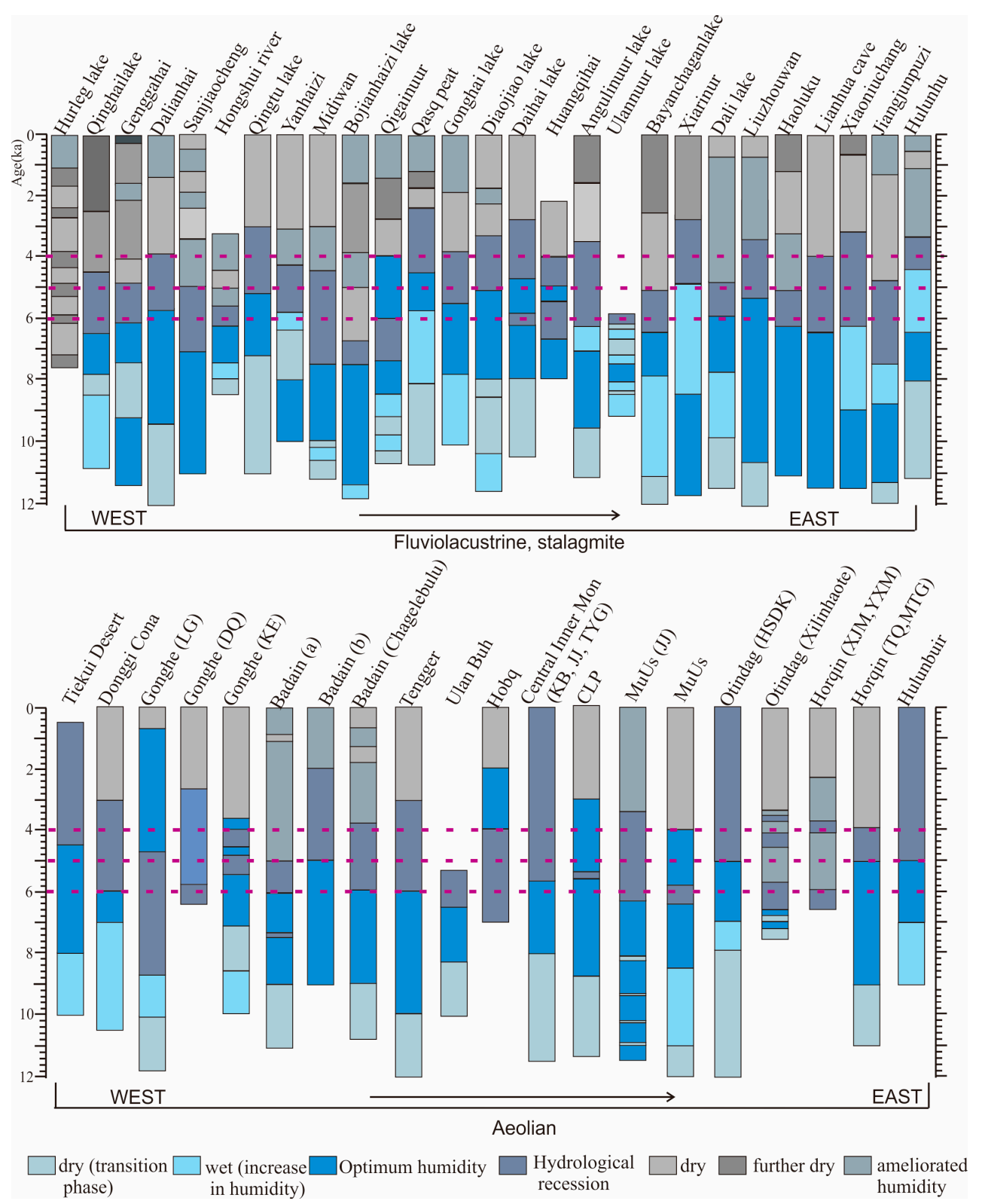

Figure 6. Synthetical published records of the Holocene hydroclimate variation from fluvio-lacustrine, stalagmite, and aeolian (loess) deposits along the EASM margin, shown in Table 1. Dashed lines indicate hydrological climate conditions $6 \mathrm{ka}, 5 \mathrm{ka}$, and $4 \mathrm{ka}$ ago. Data is provided by part of the published reference in Table 2.

\section{Discussion}

\subsection{Asynchronous Onset of Mid-Holocene Moisture Decline}

Aeolian deposits from the XJM, YXM, and HXT sections indicated that there was a remarkably arid interval at $\sim 6-5 \mathrm{ka}$ in the Horqin sandy land, which interrupted the development of paleosols (Figure 2). In addition, C4 biomass values from TQ (Figure 2) and the MTG section in the Horqin also abruptly decreased around $5.6 \mathrm{ka}$ [74]. The episode of hydrological recession lasted from about several hundred years to a millennium from the west to the east along the EASM boundary belt. Semi-quantitative moisture reconstruction obtained from integrated pollen data along the belt implied a maximum moist phase at 9.5-6 ka, and then main changes primitively began at $\sim 6-5 \mathrm{ka}$, mostly due to tree decline [54,55]. The analysis of recorded dates of aeolian deposits in northeastern sandy lands suggested mobile dune states at $\sim 6-4 \mathrm{ka}$, and a substantial decline in dune stable states $\sim 5-4 \mathrm{ka}$ 
ago [57]. On the CLP synthetic frequency distribution of ages from loess and paleosols, it suggests a significant retreat of the EASM, and consequentially, climatic fluctuations from around $\sim 6$ to $5 \mathrm{ka}$ (Figure 6) [50].

In the western CLP, pollen assemblages, mollusk fauna, grain size, $\mathrm{CaCO}_{3}$, and organic matter indicated that the climate was wet at 8.3-7.4 ka, distinctly humid and warm at 7.4-6.7 ka, semi-humid from 6.7-6.3 ka, and semi-arid at 6.4-4 ka [25]. Furthermore, Guo [147] compared the arid climatic events at $\sim 6 \mathrm{ka}$ in northern China with northern Africa on a millennial-scale and suggested that the climatic fluctuation at $\sim 6 \mathrm{ka}$ in China was large-scale regional rather than local events. This confirms unambiguously that humidity recession was concentrated at $\sim 6 \mathrm{ka}$ in northern China, yet some sites retreated as early as $\sim 8 \mathrm{ka}$, such as in Yanhaizi and Midiwan (Figure 6). Using numerical techniques, pollen-based quantitative climatic reconstructions demonstrated that from 6.2-5.1 ka was the wettest and warmest interval in Daihai Lake, with cold and dry events identified as occurring 6 ka ago [99], which is generally in accordance with Xiao's studies $[100,101]$. However, pollen assemblages indicative of vegetation changes from sparse-wood grassland to mixed conifer, broad-leaved forests suggested that the HO occurred prior to $7 \mathrm{ka}$ ago on the basis of the highest pollen concentrations of the period in Daihai Lake [148]. Both of the records originated from the same core and reached different results. The divergence of the results may be attributed to different analysis methods or different interpretations of pollen assemblages by different pollen analyzers [99].

Not only was the initial time of the hydrographic recession asynchronous, but the degeneration degree was also inconsistent. In Dali Lake, a significant variation of mineral content indicated dramatically decreased inflowing water and decreased lake levels from 5.9 to $4.8 \mathrm{ka}$ ago. Since $4.8 \mathrm{ka}$, quartz and albite percentages recovered to higher levels compared with the preceding period of $5.9-4.8 \mathrm{ka}$, but were much lower than before $5.9 \mathrm{ka}$, which suggests that drainage losses of lake water were much less from 4.8 to 0 ka than from 5.9 to $4.8 \mathrm{ka}$ [149]. Compared with Dali's relatively large-amplitude oscillation of the hydrographic environment at $5.9-4.8 \mathrm{ka}$, pollen-derived, reconstructed $\mathrm{Pa}$ in Hulun lake declined slightly (fluctuating at around $330 \mathrm{~mm}$ at $6.4-4.4 \mathrm{ka}$ ) compared to the last stage (around $340 \mathrm{~mm}$ ); until the period of 4.4-3.3 ka, the lowest Pa of the entire Holocene with an average of $260 \mathrm{~mm}$ was registered [115]. Hence, we may not necessarily expect a uniform pattern of environmental deterioration in northern China. Large between-site variability may be a response to the interactions of large-scale generally dynamic mechanisms and regional controlling factors [66]. In addition, irregularity-sensitive responses of the climatic index to climate change, different temporal resolutions, or inadequate dating precision may partly amplify regional differences $[33,99]$.

\subsection{Possible Mechanism for Holocene Hydroclimate Change}

In semiarid North China, along the peripheral realm of the EASM, climate is driven by large-scale climate forcing, including the EASM and the Indian summer monsoon (ISM). The relationship between EASM and ISM is dynamic and more complicated than synchronous or asynchronous, relating to atmosphere-land-ocean-vegetation interactions [150]. Aside from AM circulation, mid-latitude westerlies also played a part in mediating the influence of monsoon circulations. Concurrently, topography and regional vegetation factors might have amplified spatial complexity $[53,66,151]$.

Earth's stronger orbital forcing of summer insolation during the early-mid Holocene enhanced monsoon activity and pulled the northerly shift from the Intertropical Convergence Zone (ITCZ) [152,153], leading to abundant precipitation. The decline in monsoonal precipitation during the middle-late Holocene may be intimately associated with steeper reductions in summer insolation after 6 ka (Figure 7a) and the southerly shift of the ITCZ [154]. 


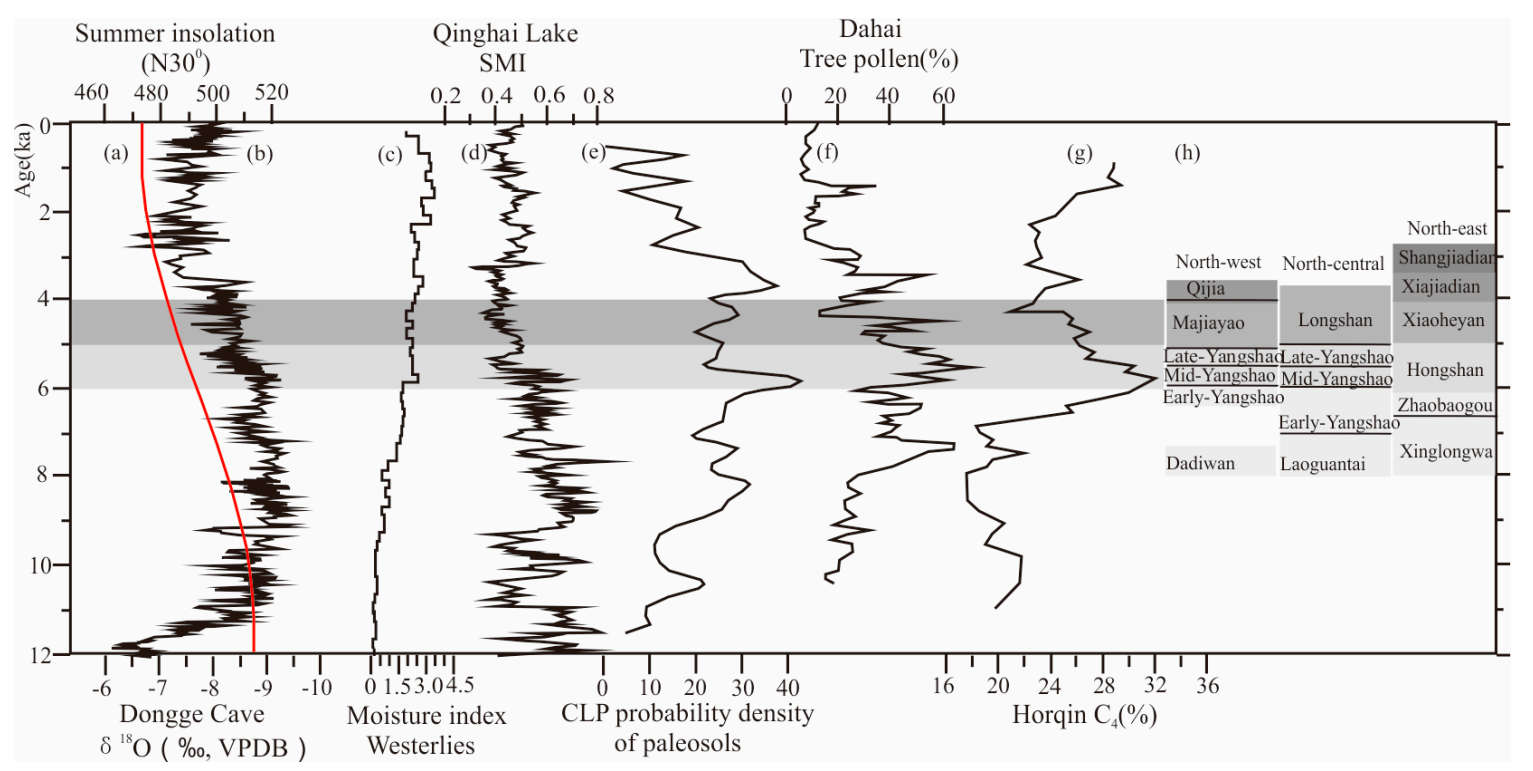

Figure 7. Possible relationship between culture rising and waning and climatic evolution along EASM margin. (a) $30^{0}$ summer insolation [155]; (b) Dongge cave speleothem $\delta^{18}$ O records $[45,46]$; (c) westerlies' climate index in arid Asia [156]; (d) EASM index (SMI) in Qinghai lake [157]; (e) probability density of paleosols in Chinese Loess Plateau [50]; (f) pollen percentages at Daihai Lake [100]; (g) variation of $C_{4}$ biomass in the Horqin sandy land [74]; (h) multi-culture evolution along EASM margin. From left to right are the western, central, and eastern portions of te EASM margin.

In addition, the westerlies' mediating role should not be overlooked. During the early Holocene, still-large ice-sheets at high latitudes modulated and reduced air temperature, and discharges of large meltwater from the ice-sheets also reduced the Northern Atlantic Ocean's surface temperature, with an increased latitudinal temperature gradient. All factors worked together, resulting in relatively dry westerlies and little precipitation in central Asia [151]. An increasingly wet interval during the mid-late Holocene was associated with increased winter solar insolation (Figure 7c) [156] and the change of external boundary conditions, such as ice sheets, meltwater fluxes, and $\mathrm{CO}_{2}$ concentration. The westerlies probably transported water vapor from the North Atlantic Ocean and inland seas and lakes, such as the Mediterranean, Black, and Caspian Seas, along the westerly cyclonic storm paths [158]. The influence of westerlies could penetrate eastwardly, even to northeastern China [159], which probably restricted the northward stretch of the subtropical monsoonal rain belt [160]. The interaction and competition of the monsoon and the westerlies may have led to complex changes and spatial heterogeneity along the transitional belt [66].

Complex geographical configuration is also related to the spatial asynchronization of climatic changes, especially in the Tibetan Plateau (TP). Between the low elevation in Hurleg lake (2800 m a.s.l.) and the high elevation in Qinghai lake (3200 $\mathrm{m}$ a.s.1.), inconsistent hydroclimate changes might be attributed to a topographically-caused, strong uplift motion of air mass over the TP, and consequently intensified subsidence of air mass in the surrounding low-elevation areas [71,151]. Similarly, aside from the influence of topographic differences, climatic deviation between Qinghai Lake and the Zoige Basin (3500 $\mathrm{m}$ a.s.l.) is also associated with the different relative position to the EASM and ISM [161]. In addition, vegetation growth and land-surface characteristics have significant effects on regional climate; accordingly, climate was sensitive to land-surface feedback, especially in semi-arid/arid regions [162]. The exchange of water and energy of vegetation-atmosphere-soil was affected by the intersection of vegetation types and leaf-area index. Feedback dynamically responded to regional climatic variations as vegetation changes. A slight modification in vegetation type would significantly change the surface albedo and near-surface potential heat to change the dynamic circulation of water and energy of each component; thus, influencing regional hydrothermal configuration $[66,162]$. Hence, 
the irregular pattern of the Holocene hydroclimate condition was likely caused by different regional responses to the coupling of solar-driven AM circulation and the westerlies, as well as the differences in the re-arrangement of hydrothermal configuration.

\subsection{Influence of Hydrographic Recession on Neolithic Culture's Development}

Even though the vicissitudes of prehistoric culture were mainly driven by climate fluctuations $[24,163]$, similar climatic conditions would generate distinct social outcomes (the flourishing or collapse of culture) because of imperative subsistence strategies regulating the relationship between humans and the environment $[164,165]$, the various degrees of climatic deterioration, and the impact of the contextual factors of those cultures [24,164]. More economical and socially specialized societies might be more vulnerable to any abrupt environmental transition [29]. Under the background of $\mathrm{HO}$, environmental degeneration at $\sim 6-5$ ka was probably of minor amplitude within the thresholds of Earth's ecosystem, when annual precipitation was less than $400 \mathrm{~mm}$, and mean annual temperature was colder than $4.5^{\circ} \mathrm{C}$, a $1{ }^{\circ} \mathrm{C}$ decrease relative to the present in northern China [99].

Accurate spatiotemporal changes of archaeological sites (Figures 8 and 9) reflecting the prehistoric population dynamics are crucial for the proper evaluation of their driving mechanisms for ascribing paleoclimate changes to human-induced forcing [62]. In Figure 8, we can see that some regions did not allow for detecting differences between early and middle Neolithic time slices because of not subdividing the Neolithic into finer cultural units, while other regions with higher temporal resolution provided archaeological data for the middle Neolithic time slices. In the Shaanxi provinces, for example, an increment of archaeological sites from 159 to 341 sites marks a transition from the early Yangshao culture to the middle Yangshao culture [62]. In Figure 9, six time-slices from 41,260 archaeological sites along the EASM margin were used to re-establish the spatiotemporal distribution of archaeological sites of the region. A comparison of early Neolithic (8-6 ka) and mid-late Neolithic (6-4 ka) time slices revealed that the number of archaeological sites increased substantially and expanded from the south to the north within the Taihang Mountains [62]; the sites are mainly distributed in the middle to lower reaches of the Yellow River, even far into the upper reaches.

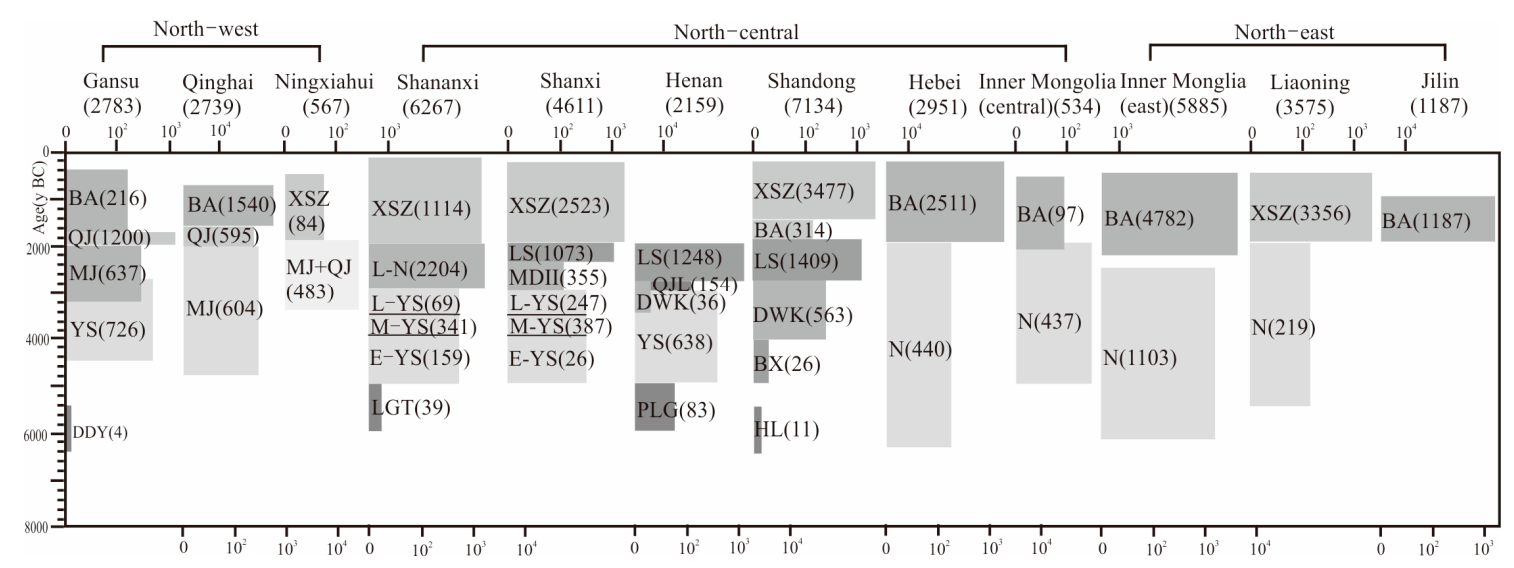

Figure 8. Chronological diagrams and change in the number of archaeological sites from the Neolithic and Bronze Ages and the early dynastic periods along the provinces of the EASM's margin. Data were provided by Hosner [62]. N, undistinguished Neolithic cultures; L-N, late Neolithic culture; DDY, Dadiwan culture; LGT, Laoguantai culture; PLG, Peiligang culture; HL, Houli culture; YS, Yangshao culture; E-YS, early Yangshao culture; M-YS, middle Yangshao culture; L-YS, late Yangshao culture; MJ, Majiayao culture; QJ, Qijia culture; DWK, Dawenkou culture; MDII, Miaodigou II culture; BX, Beixin culture; QJL, Qujialing culture; LS, Longshan culture; BA, Bronze culture; XSZ, undistinguished Xia-Shang-Zhou dynasty period. Numbers in the brackets represent number of archaeological sites. 

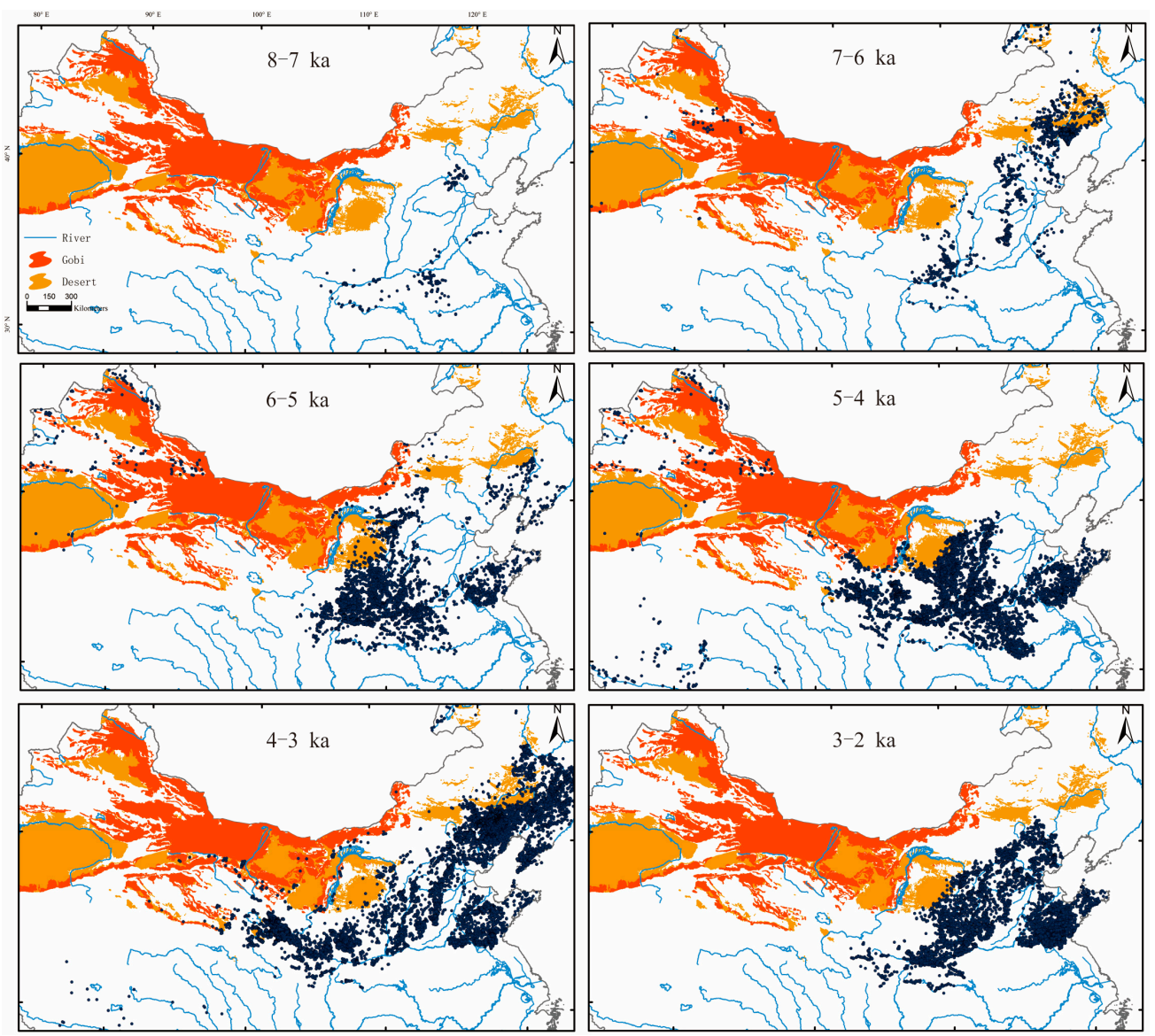

Figure 9. Holocene spatiotemporal variation of archaeological sites along EASM margin. These maps were compiled according to data of archaeological sites provided by Honser [62].

During the $\mathrm{HO}$ in the northeastern fringe, the strengthened monsoon brought more precipitation to the Western Liaohe basin, and hence, favorable climate benefits for the thriving of early Neolithic cultures, such as during the Xinglongwa and Zhaobaogou periods. Rain-watered agriculture began to develop at the time [5] when fishing, hunting, and gathering were the primary subsistence strategies [27,164]. Analysis of stable carbon isotopes in human bones revealed that C3 plants obtained by gathering were part of the daily diet in the region [26,166]. Flotation results demonstrated that foxtail millet and broomcorn millet became the most important crops during the Hongshan phase in the West Liao River Basin [167]. As the hydroclimate was not humid enough for practicing large-scale agricultural activities, the mid-late Hongshan culture could have been sustained at a low production level for the long term, and Hongshan humans engaged in other subsistence strategies [164]. Rice-starch grains of the Hongshan phase from grinding stones indicated that, at $4000 \mathrm{BC}$ - the earliest evidence, rice appeared in the Liaodong peninsula [168]. The rare appearance of rice in the Hongshan period denoted as an exotic food is possibly attributable to interactions with other contemporary communities, such as in the Yellow River basin [20], where domesticated rice had become more widespread during the Yangshao culture (5000-3000 BC) [26,169], demonstrating the development of social complexity and the emergence of elite groups in the Hongshan culture [20]. During the mid-late Hongshan culture, analysis of ceramic assemblages with relatively high proportions of exquisite, advanced ceramics, and the spatial patterning of house structures in archaeological sites of the northeastern region, indicated greater social prestige. Moreover, the interpretable multidimensional scaling results for lithic assemblages clearly reflected some degree of productive differentiation or low-intensity specialization, and economic interdependence between households, reflecting kinship links or other kinds of social bonds [170-172]. The most impressive complex ritual differentiation in death is connected with difference in prestige, which was reflected in platform burials with jade carved into 
symbolic forms [171,172]. However, prestige difference seems to not have spilled over into every aspect of village interactions [172]. Obviously, the social change trajectories of mid-late Hongshan culture were identical with contemporaneous Yanshao culture in northern-central China, where productivity and wealth differentiation were considerably more strongly developed [172].

In the northern-central region, including the Wei River valley, the Guanzhong Basin, the Wei and Yellow River confluence, and Inner Mon (central and south), there are a high concentration of archaeological sites assigned to the mid-Yangshao culture (Figure 8) [62], indicating substantial population growth [61,62]. The Yiluo region, a core area of Chinese civilization in the Yellow River valley, experienced dramatic population growth, and a two-tiered settlement system spread to a large part of the region during the middle-late Yangshao periods [19,165]. Millet farming and pig domestication became more intensive in the meantime, while wild cereal and tubers collected were part of subsistence strategies $[165,173]$. Large-scale movements of populations from the southeastern regions to Henan during the late Yangshao periods, were evidenced by the presence of ceramics and typical cultural practices, such as tooth extraction, which came from the mid-late Dawenkou culture in Shangdong and Qujialing cultures in Hubei, confirming the development of greater social complexity, probably due to resource shortage as a result of environmental deterioration $[19,174]$. In the Gongzhong Basin, cereal-crop cultivation remained strong. Increased charcoal concentration at $3500 \mathrm{BC}$ revealed the expansion of human populations and agricultural activities in the region. It should be particularly noted that Poaceae decreased while the xeromorphic Fagopyrum increased gradually around 3500 BC, which indicated that rain-watered crops, such as buckwheat (Fagopyrum), were selected for cultivation by Neolithic humans to adapt to the drier climate in Guanzhong Basin [175]. In central-south Inner Mongolia, starch and phytolith analyses, as well as use-wear analysis, suggested various underground storage organs, such as yams, lily bulbs, snake gourd roots, and cattail rhizomes. They were staple foods before 3500 BC; by 3500-3000 BC, cereal-based agriculture, such as millets and Job's tears, replaced tubers and roots, and became a more important source of starchy foods. The transformation of the diet structure can probably be attributed to climatic fluctuations that might have led to the depletion of wild resources around $3500 \mathrm{BC}$. An increased number of houses and settlement sizes indicated population growth in Miaozigou village in central-south Inner Mongolia [165], where the developed Miaozigou culture inherited the property of the Miaodigou culture from the Zhongyuan region, and reached its peak in the initial stage of environmental degradation [176]. A typical jade dragon was found in the Nihewan-Huliu Basin of Hebei with obvious characteristics of the Hongshan culture, also indicating geographically different cultures meeting and coexisting $\sim 6.5-5 \mathrm{ka}$ ago $[177,178]$.

In the Gansu-Qinghai region of the northeastern Tibetan Plateau (NETP), the first emergence of millet-based agriculture was found during the early-mid Yangshao periods in Longdong basin [179]. When vegetation changed from forest-steppes to steppes in response to the climate transition from semi-humid to semi-arid during 6.3-4.0 ka in Western CLP [25], there was a rapidly increased number of archaeological sites and a dramatically expanded distribution of settlements, productive agriculture, and fine agriculture, all indicating the thriving of the Majiayao culture. Westward to the Guanting Basin in the NETP, four archeological sites were located on the third terrace of the Yellow River during the late Yangshao period ( $5.5 \mathrm{ka})$. During the Majiayao cultures ( $5.3 \mathrm{ka})$, the number of sites evidently increased, and the scale and distribution of the settlements was expanded, with settlements generally shifting toward the lower elevation areas of the region [180]. Contemporaneously, the rate of excavation of charred seeds increased from 0.71 to 34.1 grains/liter, implying the intensification of agricultural activity [180]. Farming communities of the NETP settled along the Yellow River and its tributaries at altitudes below $2500 \mathrm{~m}$ a.s.l., and foxtail millet and broomcorn millet constituted the primary crops during the late Yangshao, Majiayao, and Qijia periods; that was all regarded as an upstream extension of the longstanding tradition of millet-based agriculture into the NETP, which developed and became widespread along the middle and lower reaches of the Yellow River at an earlier time [181]. Large-scale cultural expansion during the late Yangshao (3500 BC) and Majiayao (3300 BC) periods may be associated with the increase of population, and the relatively dry climate led 
to the contradiction of Yangshao human-land utilization, stimulating the expansion of the Yangshao culture in central China [177].

In the fragile environmental areas of the north, northwest, and northeast in China, certain geographic limitations may be lessened due to climate deterioration at $\sim 5.5 \mathrm{ka}$ [61]. Changes in subsistence strategies represented adaptions to climate change and population growth, which promoted cultural richness and even political and economic development [61-63,182].

\section{Conclusions}

The deposition of aeolian sand and the change of $\mathrm{Re}$ and $\mathrm{Rb} / \mathrm{Sr}$ ratio in the strata based on the OSL ages indicated the relative dry mid-Holocene climate 6-5 ka ago in the Horqin sand land. Synthetical records of Holocene fluvial-lacustrine, stalagmite, loess, and aeolian deposits indicated hydroclimatic recession between $\sim 6-5 \mathrm{ka}$ from the $\mathrm{HO}$, although they were not entirely consistent in onset, time of duration, or degree of recession along the peripheral EASM realm. The spatiotemporal complexity may be attributed to orbit-induced weakening of summer solar insolation, and the interactions of the $\mathrm{AM}$ and westerlies, as well as topographical and regional vegetation factors.

In response to hydroclimatic recession from the $\mathrm{HO}$ and regional population-resource pressure, Neolithic humans adjusted their subsistence strategies, which involved intensive agricultural activities, increasing the complexity and spread of settlement systems, northern and northwestern expansion, and integration of region-specific Neolithic cultures.

Author Contributions: Conceptualization, W.X., H.J., and B.L.; methodology, W.X., H.J., and B.L.; resources, H.J., B.L., and W.X.; investigation, H.J., B.L., W.X., and Z.L.; software, W.X. and Z.L.; visualization, W.X.; writing-original draft preparation, W.X.; writing—review and editing, H.J., L.S., and W.X.; supervision, H.J.

Funding: This research was funded by the National Natural Science Foundation of China (grant numbers 41977393, 41671204, and 41501220).

Acknowledgments: This research was funded by the National Natural Science Foundation of China (numbers 41977393,41671204 , and 41501220). We are grateful to the editor and anonymous reviewers who spent considerable time and energy providing valuable suggestions and critical comments on the paper.

Conflicts of Interest: The authors declare no conflict of interest.

\section{References}

1. Childe, V.G. The urban revolution. Town Plan. Rev. 1950, 21, 3-17. [CrossRef]

2. Liu, L.; Duncan, N.A.; Chen, X.C.; Zhao, H.; Ji, P. Changing Patterns of Plant-based Food Production During the Neolithic and Early Bronze Age in Central-south Inner Mongolia. Quat. Int. 2016, 419, 36-53. [CrossRef]

3. Dodson, J.R.; Li, X.Q.; Zhou, X.Y.; Zhao, K.L.; Sun, N.; Atahan, P. Origin and spread of wheat in China. Quat. Sci. Rev. 2013, 72, 108-111. [CrossRef]

4. Crawford, G. Agricultural origins in north China pushed back to the Pleistocenee Holocene boundary. Proc. Natl. Acad. Sci. USA 2009, 106, 7271-7272. [CrossRef] [PubMed]

5. Zhao, Z.J. The process of origin of agriculture in China: Archaeological evidence from flotation results. Quat. Sci. 2014, 34, 73-84. (In Chinese)

6. Sandweiss, D.H.; Maasch, K.A.; Anderson, D.G. Transitions in the mid-Holocene. Science 1999, 283, 499-500. [CrossRef]

7. Mayewski, P.A.; Rohling, E.E.; Stager, J.C.; Karlen, W.; Maasch, K.A.; Meeker, L.; Meyerson, E.A.; Gasse, F; Kre veld, S.V.; Holmgren, K.; et al. Holocene climate variability. Quat. Res. 2004, 62, 243-255. [CrossRef]

8. Marchant, R.; Hooghiemstra, H. Rapid environmental change in African and South American tropics around 4000 years before present: A review. Earth Sci. Rev. 2004, 66, 217-260. [CrossRef]

9. Drysdale, R.; Zanchetta, G.; Hellstrom, J.; Maas, R.; Fallick, A.; Pickett, M.; Cartwright, I.; Piccini, L. Late Holocene drought responsible for the collapse of Old World civilizations is recorded in an Italian cave flowstone. Geology 2006, 34, 101-104. [CrossRef]

10. Marshall, M.H.; Lamb, H.F.; Huws, D.; Davies, S.J.; Bates, R.; Bloemendal, J.; Boyle, J.; Leng, M.J.; Umer, M.; Bryant, C. Late Pleistocene and Holocene drought events at Lake Tana, the source of the Blue Nile. Glob. Planet Chang. 2011, 78, 147-161. [CrossRef] 
11. Prasad, V.; Farooqui, A.; Sharma, A.; Phartiyal, B.; Chakraborty, S.; Bhandari, S.; Raj, R.; Singh, A. Mid-late Holocene monsoonal variations from mainland Gujarat, India: A multi-proxy study for evaluating climate culture relationship. Palaeogeogr. Palaeoclimatol. Palaeoecol. 2014, 397, 38-51. [CrossRef]

12. Leipe, C.; Demske, D.; Tarasov, P.E.; HIMPAC Project Members. A Holocene pollen record from the northwestern Himalayan lake Tso Moriri: Implications for palaeoclimatical and archaeological research. Quat. Int. 2014, 348, 93-112. [CrossRef]

13. Lillios, K.T.; Blanco-Gonzalez, A.; Drake, B.L.; Lopez-Saez, J.A. Mid-late Holocene climate, demography, and cultural dynamics in Iberia: A multi-proxy approach. Quat. Sci. Rev. 2016, 135, 138-153. [CrossRef]

14. Bond, G.; Kromer, B.; Beer, J.; Muscheler, R.; Evans, M.N.; Showers, W.; Hoffmann, S.; Lotti-Bond, R.; Hajdas, I.; Bonani, G. Persistent solar influence in North Atlantic climate during the Holocene. Science 2001, 294, 2130-2136. [CrossRef] [PubMed]

15. Wright, R. The Ancient Indus: Urbanism Economy and Society, Case Studies in Early Societies; Cambridge University Press: New York, NY, USA, 2010.

16. De Menocal, P.B. Cultural responses to climate change during the late Holocene. Science 2001, 292, 667-673. [CrossRef]

17. Jin, G.Y.; Liu, T.S. Mid-Holocene climate change in North China, and the effect on cultural development. Chin. Sci. Bull. 2002, 47, 408-413. [CrossRef]

18. Wu, W.X.; Liu, T.S. Possible role of the 'Holocene Event 3' on the collapse of Neolithic Cultures around the Central Plain of China. Quat. Int. 2004, 117, 153-166.

19. Liu, L.; Chen, X.C.; Lee, Y.K.; Wright, H.; Rosen, A. Settlement patterns and development of social complexity in the Yiluo region, North China. J. Field Archaeol. 2004, 29, 75-100. [CrossRef]

20. Liu, L.; Duncan, N.A.; Chen, X.C.; Ji, P. Plant-based subsistence strategies and development of complex societies in Neolithic Northeast China: Evidence from grinding stones. J. Archaeol. Sci. Rep. 2016, 7, 247-261. [CrossRef]

21. Dong, G.H.; Jia, X.; An, C.B.; Chen, F.H.; Zhao, Y.; Tao, S.C.; Ma, M.M. Mid-Holocene climate change and its effect on prehistoric cultural evolution in eastern Qinghai Province, China. Quat. Res. 2012, 77, $23-30$. [CrossRef]

22. Liu, F.G.; Feng, Z.D. A dramatic climatic transition at $\sim 4000$ cal. yr BP and its cultural responses in Chinese cultural domains. Holocene 2012, 22, 1181-1197. [CrossRef]

23. Li, F.; Wu, L.; Zhu, C.; Zheng, C.G.; Sun, W.; Wang, X.H.; Shao, S.X.; Zhou, Y.; He, T.T.; Li, S.Y. Spatial-temporal distribution and geographic context of Neolithic cultural sites in the Hanjiang River Basin, Southern Shaanxi, China. J. Archaeol. Sci. 2013, 40, 3141-3152. [CrossRef]

24. Jia, X.; Sun, Y.G.; Wang, L.; Sun, W.F.; Zhao, Z.J.; Lee, H.F.; Huang, W.B.; Wu, S.Y.; Lu, H.Y. The transition of human subsistence strategies in relation to climate change during the Bronze Age in the West Liao River Basin, Northeast China. Holocene 2016, 26, 781-789. [CrossRef]

25. An, C.B.; Feng, Z.D.; Tang, L.Y. Environmental change and cultural response between 8000 and 4000 cal yr B.P. in the western Loess Plateau, northwest China. J. Quat. Sci. 2004, 19, 529-535. [CrossRef]

26. Liu, L.; Chen, X. The Archaeology of China: From the Late Palaeolithic to the Early Bronze Age; Cambridge University Press: Cambridge, UK, 2012.

27. Yuan, Y.Y. Cultural evolution and spatial-temporal distribution of archaeological sites from 9.5-2.3 ka BP in the Yan-Liao region, China. J. Geogr. Sci. 2019, 29, 449-464. [CrossRef]

28. Morrison, K.D. Archaeology: Failure and how to avoid it. Science 2006, 440, 752-754.

29. O'Sullivan, P. The 'collapse' of civilizations: What palaeoenvironmental reconstruction cannot tell us, but anthropology can. Holocene 2008, 18, 45-55. [CrossRef]

30. Gasse, F.; Van Campo, E. Abrupt post-glacial climate events in West Asia and North Africa monsoon domains. Earth Planet. Sci. Lett. 1994, 126, 435-456. [CrossRef]

31. Sarkar, S.; Prasad, S.; Wilkes, H.; Riedel, N.; Stebich, M.; Basavaiah, N.; Sachse, D. Monsoon source shifts during the drying mid-Holocene: Biomarker isotope based evidence from the core 'monsoon zone' (CMZ) of India. Quat. Sci. Rev. 2015, 123, 144-157. [CrossRef]

32. deMenocal, P.B.; Ortiz, J.; Guilderson, T.; Adkins, J.; Sarnthein, M.; Baker, L.; Yarusinsky, M. Abrupt onset and termination of the Africa Humid period: Rapid climate responses to gradual insolation forcing. Quat. Sci. Rev. 2000, 19, 347-361. [CrossRef] 
33. Magny, M.; Haas, J.N. A major widespread climatic change around 5300 cal. yr BP at the time of Alpine Iceman. J. Quat. Sci. 2004, 19, 423-430. [CrossRef]

34. Jimenez-Moreno, G.; Anderson, R.S. Holocene vegetation and climate change recorded in alpine bog sediments from the Borreguiles de la Virgen, Sierra Nevada, southern Spain. Quat. Res. 2012, 77, 44-53. [CrossRef]

35. Jambrina-Enríquez, M.; Rico, M.; Moreno, A.; Leira, M.; Barnardez, P.; Prego, R.; Recio, C.; Valero-Garces, B.L. Timing of deglaciation and postglacial environ- mental dynamics in NW Iberia: The Sanabria Lake record. Quat. Sci. Rev. 2014, 94, 136-158.

36. Bond, G.; Showers, W.; Cheseby, M.; Lotti, R.; Almasi, P.; de Menocal, P.; Priore, P.; Cullen, H.; Hajdas, I.; Bonani, G. A pervasive millennial-scale cycle in the North Atlantic Holocene and glacial climates. Science 1997, 294, 2130-2136. [CrossRef]

37. Baker, R.G.; Bettis, E.A., III; Denniston, R.F.; Gonzalez, L.A. Plant remains, alluvial chronology, and cave speleothem isotopes indicate abrupt Holocene climatic change in Midwestern USA. Glob. Planet. Chang. 2001, 28, 285-291. [CrossRef]

38. Haug, G.H.; Hughen, K.A.; Sigman, D.M.; Peterson, L.C.; Rohl, U. Southward migration of the intertropical convergence zone through the Holocene. Science 2001, 293, 1304-1308. [CrossRef]

39. Masson, V.; Vimeux, F.; Jouzel, J.; Morgan, V.; Delmotte, M.; Ciais, P.; Hammer, C.; Johnsen, S.; Lipenkov, V.Y.; Mosley-Thompson, E.; et al. Holocene climate variability in Antarctica based on 11 ice-core isotopic records. Quat. Res. 2000, 54, 348-358. [CrossRef]

40. Lamy, F.; Rühlemann, C.; Hebbeln, D.; Wefer, G. High-and low-latitude climate control on the position of the southern Peru-Chile Current during the Holocene. Palaeogeogr. Palaeoclimatol. Palaeoecol. 2002, 17, 16/1-16/10. [CrossRef]

41. Cai, Y.; Zhang, H.; Cheng, H.; An, Z.S.; Edwards, R.L.; Wang, X.F.; Tan, L.C.; Liang, F.Y.; Wang, J.; Kelly, M. The Holocene Indian monsoon variability over the southern Tibetan Plateau and its teleconnections. Earth Planet Sci. Lett. 2012, 335-336, 135-144. [CrossRef]

42. Thompson, L.G.; Mosley-Thompson, E.; Davis, M.E.; Bolzan, J.F.; Dai, J.; Klein, L.; Yao, T.; Wu, X.; Xie, Z.; Gundestrup, N. Holocene-Late Pleistocene climatic ice core records from Qinghai-Tibetan Plateau. Science 1989, 246, 474-477. [CrossRef]

43. Cai, Y.J.; Zhang, M.L.; Peng, Z.C.; Lin, Y.S.; An, Z.S.; Zhang, Z.F.; Cao, Y.N. The $\delta^{18}$ O variation of a stalagmite from Qixingcave, Guizhou Province and indicated climate change during Holonece. Chin. Sci. Bull. 2001, 40, 1904-1907. [CrossRef]

44. Zhou, W.; Yu, X.; Jull, A.J.T.; Burr, G.; Xiao, J.Y.; Lu, X.; Xian, F. High-resolution evidence from southern China of an early Holocene optimum and a mid-Holocene dry event during the past 18,000 years. Quat. Res. 2004, 62, 39-48. [CrossRef]

45. Wang, Y.J.; Cheng, H.; Edwards, R.L.; He, Y.Q.; Kong, X.G.; An, Z.S.; Wu, J.Y.; Kelly, M.J.; Dykoski, C.A.; Li, X.D. The Holocene Asian monsoon: Links to solar changes and North Atlantic climate. Science 2005, 308, 854-857. [CrossRef]

46. Dykoski, C.A.; Edwards, R.L.; Cheng, H.; Yuan, D.X.; Cai, Y.J.; Zhang, M.L.; Lin, Y.S.; Qing, J.M.; An, Z.S.; Revenaugh, J. A high resolution, absolute-dated Holocene and deglacial Asian monsoon record from Dongge Cave, China. Earth Planet Sci. Lett. 2005, 233, 71-86. [CrossRef]

47. Li, Y.P.; Ma, C.M.; Zhou, B.; Cui, A.N.; Zhu, C.; Huang, R.; Zheng, C.G. Environmental processes derived from peatland geochemistry since the last deglaciation in Dajiuhu, Shennongjia, Central China. Boreas 2016, 45, 423-438. [CrossRef]

48. Goldsmith, Y.; Broecker, W.S.; Xu, H.; Polissar, P.J.; deMenocal, P.B.; Porat, N.; Lan, J.; Cheng, P.; Zhou, W.J.; An, Z. Northward extent of East Asian monsoon covaries with intensity on orbital and millennial timescales. Proc. Natl. Acad. Sci. USA 2017, 114, 1817-1821. [CrossRef]

49. Goldsmith, Y.; Broecker, W.S.; Xu, H.; Polissar, P.J.; deMenocal, P.B.; Porat, N.; Lan, J.; Cheng, P.; Zhou, W.J.; An, Z. Reply to Liu et al.: East Asian summer monsoon rainfall dominates Lake Dali lake area changes. Proc. Natl. Acad. Sci. USA 2017, 114, 2989-2990. [CrossRef]

50. Wang, H.P.; Chen, J.H.; Zhang, X.J.; Chen, F.H. Palaeosol development in the Chinese Loess Plateau as an indicator of the strength of the East Asian summer monsoon: Evidence for a mid-Holocene maximum. Quat. Int. 2014, 334, 155-164. [CrossRef] 
51. Bai, Y.J.; Zhang, P.Z.; Gao, T.; Yu, R.Z.; Zhou, P.C.; Cheng, H. The 5400 a BP extreme weakening event of the Asian summer monsoon and cultural evolution. Sci. China Earth Sci. 2017, 60, 1171-1182. [CrossRef]

52. Shen, J.; Liu, X.Q.; Wang, S.M.; Ryo, M. Palaeoclimatic changes in the Qinghai Lake area during the last 18,000 years. Quat. Int. 2005, 136, 131-140.

53. Herzschuh, U.; Winter, K.; Wunnemannc, B.; Li, S.J. A general cooling trend on the central Tibetan Plateau throughout the Holocene recorded by the Lake Zigetang pollen spectra. Quat. Int. 2006, 154-155, 113-121. [CrossRef]

54. Zhao, Y.; Yu, Z.C.; Chen, F.H.; Zhang, J.W.; Yang, B. Vegetation response to Holocene climate change in monsoon-influenced region of China. Earth Sci. Rev. 2009, 97, 242-256. [CrossRef]

55. Zhao, Y.; Yu, Z.C.; Chen, F.H. Spatial and temporal patterns of Holocene vegetation and climate changes in arid and semi-arid China. Quat. Int. 2009, 194, 6-18. [CrossRef]

56. Wang, W.; Feng, Z.D. Holocene moisture evolution across the Mongolian Plateau and its surrounding areas: A synthesis of climatic records. Earth Sci. Rev. 2013, 122, 38-57. [CrossRef]

57. Guo, L.C.; Xiong, S.F.; Ding, Z.L.; Jin, G.Y.; Wu, J.B.; Ye, W. Role of the mid Holocene environmental transition in the decline of late Neolithic cultures in the deserts of NE China. Quat. Sci. Rev. 2018, 190, 98-113. [CrossRef]

58. Morrill, C.; Overpeck, J.T.; Cole, J.E. A synthesis of abrupt changes in the Asian summer monsoon since the last deglaciation. Holocene 2003, 13, 465-476. [CrossRef]

59. Shanahan, T.M.; Mckay, N.P.; Hughen, K.A.; Overpeck, J.T.; Ottobliesner, B.; Heil, C.W.; King, J.; Scholz, C.A.; Peck, J. The time-transgressive termination of the African Humid Period. Nat. Geos. 2015, 8, 140-144. [CrossRef]

60. Roman, H.S.F.; Herrs, C. Staaten der Frühzeit-Ursprünge und Herrschaftsformen (Translated by Zhao Ronghuan); Peking University Press: Beijing, China, 1998; pp. 1-395. (In Chinese)

61. Wu, W.X.; Zheng, H.B.; Hou, M.; Ge, Q.S. The 5.5 cal ka BP climate event, population growth, circumscription and the emergence of the earliest complex societies in China. Sci. China Earth Sci. 2018, 61, 134-148. [CrossRef]

62. Hosner, D.; Wagner, M.; Tarasov, P.E.; Chen, X.C.; Leipe, C. Spatiotemporal distribution patterns of archaeological sites in China during the Neolithic and Bronze Age: An overview. Holocene 2016, 26, 1576-1593. [CrossRef]

63. Wu, W.X.; Liu, T.S. 5500a BP Climatic event and its implications for the emergence of civilizations in Egypt and Mesopotamia and Neolichic Cultural development in China. Earth Sci. Front. 2002, 9, 155-163. (In Chinese)

64. Zhang, X.S. Editorial Committee of Vegetation Map of China Chinese Academy of Sciences (Ed.), Vegetation Map of the People's Republic of China (1:1,000,000), Vegetation Map of China and its Geographic Pattern-Illustration of the Vegetation Map of The People's Republic of China (1:1 000 000); Geological Publishing House: Beijing, China, 2007.

65. Zhao, Y.; Yu, Z.C. Vegetation response to Holocene climate change in East Asian monsoon-margin region. Earth Sci. Rev. 2012, 113, 1-10. [CrossRef]

66. Wang, T. Atlas of Sandy Desert and Aeolian Desertification in Northern China; Science Press: Xi'an, China, 2014.

67. Han, G.; Zhang, G.; Dong, Y. A model for the active origin and development of source-bordering dune fields on a semiarid fluvial plain: A case study from the Xiliaohe Plain, Northeast China. Geomorphology 2007, 86, 512-524. [CrossRef]

68. Zhao, H.; Lu, Y.C.; Yin, J.H. Optical dating of Holocene sand dune activities in the Horqin sand-fields in Inner Mongolia, China, using the SAR protocol. Quat. Geochronol. 2007, 2, 29-33. [CrossRef]

69. Lu, Y.C.; Wang, X.L.; Wintle, A.G. A new OSL chronology for dust accumulation in the last 130,000 yr for the Chinese Loess Plateau. Quat. Res. 2007, 67, 152-160. [CrossRef]

70. Zhao, H.; Lu, Y.C.; Wang, C.M.; Chen, J.; Liu, J.F.; Mao, H.L. ReOSL dating of Aeolian and fluvial sediments from Nihewan Basin, northern China and its environmental application. Quat. Geochronol. 2010, 5, 159-163. [CrossRef]

71. Lai, Z.P.; Zöller, L.; Fuchs, M.; Brückner, H. Alpha efficiency determination for OSL of quartz extracted from Chinese loess. Radiat. Meas. 2008, 43, 767-770. [CrossRef]

72. Prescott, J.R.; Hutton, J.T. Cosmic ray contributions to dose rates for luminescence and ESR dating: Large depths and long term variations. Radiat. Meas. 1994, 23, 497-500. [CrossRef] 
73. Lai, Z.P.; Ou, X.J. Basic procedures of optically stimulated luminescence (OSL) dating. Prog. Geogr. 2013, 32, 684-693.

74. Munsell, C. Munsell Soil Color Chart, 2000 Revised Washable ed.; Gretagmacbeth: New Windsor, NY, USA, 2000.

75. Guo, L.C.; Xiong, S.F.; Yang, P.; Ye, W.; Jin, G.Y.; Wu, W.W.; Zhao, H. Holocene environmental changes in the Horqin desert revealed by OSL dating and $\delta 13 \mathrm{C}$ analyses of paleosols. Quat. Int. 2018, 469, 11-19. [CrossRef]

76. Zhao, C.; Yu, Z.C.; Zhao, Y.; Ito, E. Holocene millennial-scale climate variations documented by multiple lake-level proxies from Hurleg Lake in northwestern China. J. Paleolimnol. 2010, 44, 995-1008. [CrossRef]

77. Mischke, S.; Kramer, M.; Zhang, C.; Shang, H.; Herzschuh, U.; Erzinger, J. Reduced early Holocene moisture availability in the Bayan Har Mountains, northeastern Tibetan Plateau, inferred from a multi-proxy lake record. Palaeogeogr. Palaeoclimatol. Palaeoecol. 2008, 267, 59-76. [CrossRef]

78. Wang, N.; Li, Z.; Li, Y.; Cheng, H. Millennial-scale environmental changes in the asian monsoon margin during the holocene, implicated by the lake evolution of huahai lake in the hexi corridor of northwest china. Quat. Int. 2013, 313-314, 100-109. [CrossRef]

79. Mischke, S.; Zhang, C.; Börner, A.; Herzschuh, U. Lateglacial and Holocene variation in aeolian sediment flux over the northeastern Tibetan Plateau recorded by laminated sediments of a saline meromictic lake. J. Quat. Sci. 2010, 25, 162-177. [CrossRef]

80. Qiang, M.R.; Song, L.; Chen, F.H.; Li, M.Z.; Liu, X.X.; Wang, Q. A 16-ka lake-level record inferred from macrofossils in a sediment core from Genggahai Lake, northeastern Qinghai-Tibetan Plateau (China). J. Paleolim. 2013, 49, 575-590. [CrossRef]

81. Cheng, B.; Chen, F.H.; Zhang, J.W. Palaeovegetational and palaeoenvironmental changes since the last deglacial in Gonghe Basin, northeast Tibetan Plateau. J. Geogr. Sci. 2013, 23, 136-146. [CrossRef]

82. Mischke, S.; Zhang, C.J. Holocene cold events on the Tibetan Plateau. Glob. Planet. Chang. 2010, 72, $155-163$. [CrossRef]

83. Chen, F.H.; Wu, W.; Holmes, J.A.; Madsen, D.B.; Zhu, Y.; Jin, M.; Oviatt, C.G. A mid-Holocene drought interval as evidenced by lake desiccation in the Alashan Plateau, inner Mongolia, China. Chin. Sci. Bull. 2003, 48, 1401-1410. [CrossRef]

84. Yu, X.F.; Zhou, W.J.; Lars, G.F.; Xian, F.; Chen, P.; Jull, A.J.T. High-resolution peat record for Holocene monsoon history in the eastern Tibetan Plateau. Sci. China (Ser. D) 2006, 49, 615-621. [CrossRef]

85. Zhang, H.C.; Ma, Y.Z.; Wünnemann, B. A Holocene climatic record from arid northwestern China. Palaeogeogr. Palaeoclimatol. Palaeoecol. 2000, 162, 389-401. [CrossRef]

86. Ma, Y.Z.; Zhang, H.C.; Pachur, H.J.; Wunnemann, B.; Li, J.J.; Feng, Z.D. Late glacial and Holocene vegetation history and paleoclimate of the Tengger Desert, northwestern China. Chin. Sci. Bull. 2003, 48, 1457-1462. [CrossRef]

87. Chen, F.H.; Cheng, B.; Zhao, Y.; Zhu, Y.; Madsen, D.B. Holocene environmental change inferred from a high-resolution pollen record, Lake Zhuyeze, arid China. Holocene 2006, 16, 675-684. [CrossRef]

88. Zhao, Y.; Yu, Z.; Chen, F.H.; Li, J. Holocene vegetation and climate change from a lake sediment record in the Tengger Sandy Desert, northwest China. J. Arid Environ. 2008, 72, 2054-2064. [CrossRef]

89. Li, Y.; Wang, N.A.; Cheng, H.Y.; Long, H.; Zhao, Q. Holocene environmental change in the marginal area of the Asian monsoon: A record from Zhuye Lake, NW China. Boreas 2009, 38, 349-361. [CrossRef]

90. Chen, C.T.A.; Lan, H.C.; Lou, J.Y.; Chen, Y.C. The dry Holocene Megathermal in Inner Mongolia. Palaeogeogr. Palaeoclimatol. Palaeoecol. 2003, 193, 181-200. [CrossRef]

91. Li, X.J.; Zhou, W.J.; An, Z.S.; Dodson, J. The vegetation and monsoon variations at the desert-loess transition belt at Midiwan in northern China for the last $13 \mathrm{ka}$. Holocene 2003, 13, 779-784.

92. Huang, C.Q.; Guo, L.L. Pollen evidence of a humid mid-Holocene climate from Bahar Nuur, Inner Mongolia. Open Access Libr. J. 2017, 4, 34-67. [CrossRef]

93. Jiang, Y.J.; Wang, W.; Ma, Y.Z.; Li, Y.Y.; Liu, L.N.; He, J. A preliminary study on Holocene climate change of Ordos Plateau, as inferred by sedimentary record from Bojianghaizi Lake of Inner Mongolia, China. Quat. Sci. 2014, 34, 654-665. (In Chinese)

94. Sun, A.Z.; Feng, Z.D. Holocene climatic reconstructions from the fossil pollen record at Qigai Nuur in the southern Mongolian Plateau. Holocene 2013, 23, 1391-1402. [CrossRef] 
95. Wang, L.; Sarnthein, M.; Erlenkeuser, H.; Grimalt, J.; Grootes, P.; Heilig, S.; Lvanova, E.; Kienast, M.; Pelejero, C.; Pflaumann, U. East Asian monsoon climate during the Late Pleistocene: High resolution sediment records from the South China Sea. Mar. Geol. 1999, 156, 245-284. [CrossRef]

96. Liu, J.B.; Chen, J.H.; Kandasamy, S.; Chen, S.Q.; Xie, C.L.; Chen, Q.M.; Lin, B.Z.; Yu, K.F.; Xu, Q.H.; Velasco, V.M.; et al. A 14.7 ka record of earth surface processes from the arid-monsoon transitional zone of China. Earth Surf. Proc. Land. 2018, 43, 723-734. [CrossRef]

97. Chen, F.H.; Xu, Q.H.; Chen, J.H.; Birks, H.J.B.; Liu, J.B.; Zhang, S.R.; Jin, L.Y.; An, C.B.; Telford, R.J.; Cao, X.Y.; et al. East Asian summer monsoon precipitation variability since the last deglaciation. Sci. Rep. 2015, 5, 86-111. [CrossRef] [PubMed]

98. Shi, P.J.; Song, C.Q. Palynological records of environmental changes in the middle part of Inner Mongolia, China. Chin. Sci. Bull. 2003, 48, 1433-1438. [CrossRef]

99. Xu, Q.H.; Xiao, J.L.; Li, Y.C.; Tian, F.; Nakagawa, T. Pollen-based quantitative reconstruction of Holocene climate changes in the Daihai Lake area, Inner Mongolia, China. J. Clim. 2010, 23, 2856-2868. [CrossRef]

100. Xiao, J.L.; Xu, Q.H.; Xu, T.; Nakamura, X.L.; Yang, W.D.; Liang, W.D.; Inouchi, Y. Holocene vegetation variation in the Daihai Lake region of north-central China: A direct indication of the Asian monsoon climatic history. Quat. Sci. Rev. 2004, 23, 1669-1679. [CrossRef]

101. Xiao, J.L.; Wu, J.T.; Si, B.; Liang, W.D.; Nakamura, T.; Liu, B.L.; Inouchi, Y. Holocene climate changes in the monsoon/arid transition reflected by carbon concentration in Daihai Lake of Inner Mongolia. Holocene 2006, 16, 551-560. [CrossRef]

102. Shen, H.Y.; Jia, Y.L.; Guo, F. Characteristics and environmental significance of the magnetic susceptibility in sediment of Huangqihai Lake, Inner Mongolia. China. Arid Land Geogr. 2010, 33, 151-157. (In Chinese)

103. Dong, J.G.; Shen, C.C.; Kong, X.G.; Wang, H.C.; Jiang, X.Y. Reconciliation of hydroclimate sequences from the Chinese loess plateau and low-latitude East Asian summer monsoon regions over the past 14,500 years. Palaeogeogr. Palaeoclimatol. Palaeoecol. 2015, 435, 127-135. [CrossRef]

104. Liu, H.Y.; Yin, Y.; Zhu, J.L.; Zhao, F.J.; Wang, H.Y. How did the forest respond to Holocene climate drying at the forest steppe ecotone in northern China? Quat. Int. 2010, 227, 46-52. [CrossRef]

105. Wang, H.Y.; Liu, H.Y.; Zhu, J.L.; Yin, Y. Holocene environmental changes as recorded by mineral magnetism of sediments from Anguli-nuur Lake, southeastern Inner Mongolia Plateau, China. Palaeogeogr. Palaeoclimatol. Palaeoecol. 2010, 285, 30-49. [CrossRef]

106. Wang, H.Y.; Liu, H.Y.; Zhao, F.J.; Yin, L.; Zhu, J.L.; Snowball, I. Early- and mid-Holocene palaeoenvironments as revealed by mineral magnetic, geochemical and palynological data of sediments from Bai Nuur and Ulan Nuur, southeastern Inner Mongolia Plateau, China. Quat. Int. 2012, 250, 100-118. [CrossRef]

107. Jiang, W.Y.; Guo, Z.T.; Sun, X.J.; Wu, H.B.; Chu, G.Q.; Yuan, B.Y.; Hatte, C.; Guiot, J. Reconstruction of climate and vegetation changes of Lake Bayanchagan (Inner Mongolia): Holocene variability of the East Asian monsoon. Quat. Res. 2006, 65, 411-420. [CrossRef]

108. Tang, L.; Wang, X.S.; Zhang, S.Q.; Chu, G.Q.; Yun, C.; Pei, J.L.; Sheng, M.; Yang, Z.Y. High-resolution magnetic and palynological records of the last deglaciation and Holocene from Lake Xiarinur in the Hunshandake Sandy Land, Inner Mongolia. Holocene 2015, 25, 844-856. [CrossRef]

109. Fan, J.W.; Xiao, J.L.; Wen, R.L.; Zhang, S.R.; Wang, X.; Cui, L.L.; Li, H.; Xue, D.S.; Yamagata, H. Droughts in the East Asian summer monsoon margin during the last 6 kyrs: Link to the North Atlantic cooling events. Quat. Sci. Rev. 2016, 151, 88-99. [CrossRef]

110. Fan, J.W.; Xiao, J.L.; Wen, R.L.; Zhang, S.R.; Wang, X.; Cui, L.L.; Yamagata, H. Carbon and nitrogen signatures of sedimentary organic matter from Dali Lake in Inner Mongolia: Implications for Holocene hydrological and ecological variations in the East Asian summer monsoon margin. Quat. Int. 2017, 452, 65-78. [CrossRef]

111. Xiao, J.L.; Si, B.; Zhai, D.Y.; Itoh, S.; Lomtatidze, Z. Hydrology of Dali Lake in central-eastern Inner Mongolia and Holocene East Asian monsoon variability. J. Paleolim. 2008, 40, 519-528. [CrossRef]

112. Wang, H.; Liu, H.; Cui, H.; Abrahamsen, N. Terminal Pleistoncene/Holocene palaeoenvironmental changes revealed bymineral-magnetism measurements of lake sediments for Dali Nor area, southeastern Inner Mongolia Plateau, China. Palaeogeogr. Palaeoclimatol. Palaeoecol. 2001, 170, 115-132. [CrossRef]

113. Guan, Y.Y.; Wang, Y.; Yao, P.Y.; Chi, Z.Q.; Zhao, Z.L. Environmental evolution since the Holocene in the Haolaihure ancient lake, Keshiketengqi, Inner Mongolia, China. Geol. Bull. China 2010, 29, 891-900. (In Chinese) 
114. Wang, H.Y.; Liu, H.Y.; Liu, Y.H.; Cui, H.T. Mineral magnetism of lacustrine sediments and Holocene paleoenvironmental changes in Dali Nor area, southeast Inner Mongolia Plateau, China. Paleogeogr. Paleoclimatol. Paleoecol. 2004, 208, 175-193. [CrossRef]

115. Wen, R.L.; Xiao, J.L.; Chang, Z.G.; Zhai, D.Y.; Xu, Q.H.; Li, Y.C.; Itoh, S.; Lomtatidze, Z. Holocene climate changes in the mid-highlatitude-monsoon margin reflected by the pollen record from Hulun Lake, northeastern Inner Mongolia. Quat. Res. 2010, 73, 293-303. [CrossRef]

116. Yu, L.P.; Lai, Z.P. OSL chronology and palaeoclimatic implications of aeolian sediments in the eastern Qaidam Basin of the northeastern Qinghai-Tibetan Plateau. Palaeogeogr. Palaeoclimatol. Palaeoecol. 2012, 337-338, 120-129. [CrossRef]

117. Stauch, G.; IJmker, J.; Pötsch, S.; Zhao, H.; Hilgers, A.; Diekmann, B.; Dietze, E.; Hartmann, K.; Opitz, S.; Wünnemann, B.; et al. Aeolian sediments on the north-eastern Tibetan Plateau. Quat. Sci. Rev. 2012, 57, 71-84. [CrossRef]

118. Qiang, M.R.; Jin, Y.X.; Liu, X.X.; Song, L.; Li, H.; Li, F.S.; Chen, F.H. Late Pleistocene and Holocene aeolian sedimentation in Gonghe Basin, northeastern Qinghai-Tibetan Plateau: Variability, processes, and climatic implications. Quat. Sci. Rev. 2016, 132, 57-73. [CrossRef]

119. Liu, B.; Jin, H.L.; Sun, L.Y.; Sun, Z.; Sun, Z.Z.; Zhang, C.X. Holocene climatic change revealed by aeolian deposits from the Gonghe Basin, northeastern Qinghai-Tibetan Plateau. Quat. Int. 2013, 296, 231-240. [CrossRef]

120. Liu, B.; Jin, H.L.; Sun, L.Y.; Su, Z.; Zhang, C.X.; Zhao, S. History of moisture change derived from slope sediments of the eastern gonghe basin (northeastern qinghai-tibetan plateau) during the last $17 \mathrm{ka}$. Geol. J. 2016, 52, 583-593. [CrossRef]

121. Liu, B.; Jin, H.L.; Miao, Y.F.; Sun, Z.; Su, Z.Z.; Zhang, C.X. Evidence of Holocene millennial-scale climatic change from Gonghe Basin peat deposit, northeastern Qinghai-Tibet Plateau. J. Arid Environ. 2014, 106, 1-10. [CrossRef]

122. Yang, X.; Liu, T.; Xiao, H. Evolution of megadunes and lakes in the Badain Jaran Desert, Inner Mongolia, China during the last 31,000 years. Quat. Int. 2003, 104, 99-112. [CrossRef]

123. Fan, Y.X.; Zhang, F.; Zhang, F.; Liu, W.H.; Chen, X.L.; Fan, T.L.; Wang, Y.D.; Chen, F.H.; Lai, Z.P. History and mechanisms for the expansion of the BadainJaran Desert, northern China, since $20 \mathrm{ka}$ : Geological and luminescence chronological evidence. Holocene 2016, 26, 532-548. [CrossRef]

124. Guo, Y.J.; Li, B.S.; Wen, X.H.; Wang, F.N.; Niu, D.F.; Shi, Y.J.; Guo, Y.H.; Jiang, S.P.; Hu, G.G. Holocene climate variation determined from rubidium and strontium contents and ratios of sediments collected from the BadainJaran Desert, Inner Mongolia, China. Chem. Erde-Geochem. 2014, 74, 571-576. [CrossRef]

125. Peng, J.; Dong, Z.B.; Han, F.Q.; Gao, L. Aeolian activity in the south margin of the Tengger Desert in northern China since the Late Glacial Period revealed by luminescence chronology. Palaeogeogr. Palaeoclimatol. Palaeoecol. 2016, 457, 330-341. [CrossRef]

126. Zhao, H.; Li, G.Q.; Sheng, Y.W.; Jin, M.; Chen, F.H. Early-middle Holocene Lake-desert evolution during Holocene in Ulan Buh Desert, China. Palaeogeogr. Palaeoclimatol. Palaeoecol. 2012, 331-332, 31-38. [CrossRef]

127. Yang, X.P.; Forman, S.; Hu, F.G.; Zhang, D.G.; Liu, Z.T.; Li, H.W. Initial insights into the age and origin of the Kubuqi sand sea of northern China. Geomorphology 2016, 259, 30-39. [CrossRef]

128. Fan, Y.X.; Chen, X.L.; Fan, T.L.; Jin, M.; Liu, J.B.; Chen, F.H. Sedimentary and OSL dating evidence for the development of the present Hobq desert landscape, northern China. Sci. China Earth Sci. 2013, 56, 2037-2044. [CrossRef]

129. Sun, J.M.; Li, S.H.; Han, P.; Chen, Y. Holocene environmental changes in the central Inner Mongolia, based on single-aliquot-quartz optical dating and multi-proxy study of dune sands. Palaeogeogr. Palaeoclimatol. Palaeoecol. 2006, 233, 51-62. [CrossRef]

130. Huang, C.C.; Zhou, J.; Pang, J.L.; Han, Y.P.; Hou, C.H. A regional aridity phase and its possible cultural impact during the Holocene Magathermal in the Guanzhong Basin, China. Holocene 2000, 10, 135-142. [CrossRef]

131. He, Z.; Zhou, J.; Lai, Z.; Yang, L.; Liang, J.; Long, H.; Ou, X. Quartz OSL dating of sand dunes of Late Pleistocene in the Mu Us Desert in northern China. Quat. Geochronol. 2010, 5, 102-106. [CrossRef]

132. Liu, B.; Jin, H.L.; Sun, L.Y.; Sun, Z.; Zhao, S. Geochemical evidence for Holocene millennial-scale climatic and environmental changes in the southeastern Mu Us Desert, northern China. Int. J. Earth Sci. 2015, 104, 1889-1900. [CrossRef] 
133. Jia, F.F.; Lu, R.J.; Gao, S.Y.; Li, J.F.; Liu, X.K. Holocene aeolian activities in the southeastern Mu Us Desert, China. Aeolian Res. 2015, 19, 267-274. [CrossRef]

134. Gong, Z.; Li, S.H.; Sun, J.; Xue, L. Environmental changes in Hunshandake (Otindag) sandy land revealed by optical dating and multi proxy study of dune sands. J. Asian Earth Sci. 2013, 76, 30-36. [CrossRef]

135. Jin, H.L.; Su, Z.Z.; Sun, L.Y.; Sun, Z.; Zhang, H.; Jin, L.Y. Holocene climatic change in Hunshandake desert. Chin. Sci. Bull. 2004, 49, 1730-1735. [CrossRef]

136. Zeng, L.; Yi, S.W.; Lu, H.Y.; Chen, Y.Y.; Lei, F.; Xu, Z.W.; Wang, X.Y.; Zhang, W.F. Response of dune mobility and pedogenesis to fluctuations in monsoon precipitation and human activity in the Hulunbuir dune field, northeastern China, since the last deglaciation. Glob. Planet. Chang. 2018, 168, 1-14. [CrossRef]

137. Guan, Y.Z. The element, clay mineral and depositional Environment in Horqin sand land. J. Des. Res. 1992, 12, 9-15. (In Chinese)

138. Chen, J.; Wang, H.; Lu, H. Behaviors of REE and other trace elements during weathering-evidence from chemical leaching of loess and paleosol from the Luochuan section in central China. Acta Geol. Sin. 1996, 9, 290-302.

139. Goldstein, S.L. Decoupled evolution of $\mathrm{Nd}$ and $\mathrm{Sr}$ isotopes in the continental crust and the mantle. Nature 1988, 336, 733-738. [CrossRef]

140. Brass, G.W. The effect of weathering on the distribution of strontium isotopes in weathering profiles. Geochim. Cosmochim. Acta 1975, 39, 1647-1653. [CrossRef]

141. Chen, J.; An, Z.; Head, J. Variation of Rb/Sr ratios in the loess-paleosol sequences of central China during the last 130,000 years and their implications for monsoon paleoclimatology. Quat. Res. 1999, 51, 215-219. [CrossRef]

142. Liu, B.; Jin, H.L.; Sun, L.Y.; Sun, Z.; Niu, Q.H.; Xie, S.B.; Li, G.H. Holocene moisture change revealed by the $\mathrm{Rb} / \mathrm{Sr}$ ratio of aeolian deposits in the southeastern Mu Us Desert, China. Aeolian Res. 2014, 13, 109-119. [CrossRef]

143. Zhao, J.B. Migration depth and content of chemical composition in loess strata. J. Shaanxi Norm. Univ. (Natl. Sci. Ed.) 1999, 27, 103-108. (In Chinese)

144. Zhao, J.B. A new Geological theory about Eluvial zone-Theory Illuvial on Depth of $\mathrm{CaCO}_{3}$. Acta Sedimentol. Sin. 2000, 18, 29-36. (In Chinese)

145. An, C.B.; Feng, Z.D.; Barton, L. Dry or humid? mid-Holocene humidity changes in arid and semi-arid China. Quat. Sci. Rev. 2006, 25, 351-361. [CrossRef]

146. Yang, L.H.; Long, H.; Cheng, H.Y.; Hu, G.Y. OSL dating of a mega-dune in the eastern Lake Qinghai basin (northeastern Tibetan Plateau) and its implications for Holocene aeolian activities. Quat. Geochronol. 2019, 49, 165-171. [CrossRef]

147. Guo, Z.T.; Petit-Maire, N.; Kropelin, S. Holocene non-orbital climatic events in present-day arid areas of northern Africa and China. Glob. Planet. Chang. 2000, 26, 97-103. [CrossRef]

148. Li, X.Q.; Zhou, J.; Shen, J.; Weng, C.Y.; Zhao, H.L.; Sun, Q.L. Vegetation history and climatic variations during the last $14 \mathrm{ka}$ BP inferred from a pollen record at Daihai Lake, northcentral China. Rev. Palaeobot. Palynol. 2004, 132, 195-205.

149. Fan, J.W.; Xiao, J.L.; Wen, R.L.; Zhang, S.R.; Huang, Y.; Yue, J.J.; Xu, W.; Cui, L.L.; Li, H.; Xue, D.S.; et al. Mineralogy and carbonate geochemistry of the Dali Lake sediments: Implications for paleohydrological changes in the East Asian summer monsoon margin during the Holocene. Quat. Int. 2018. [CrossRef]

150. Li, Y.; Wang, N.A.; Zhou, X.H.; Zhang, C.Q.; Wang, Y. Synchronous or asynchronous holocene indian and east asian summer monsoon evolution: A synthesis on holocene asian summer monsoon simulations, records and modern monsoon indices. Glob. Planet. Chang. 2014, 116, 30-40. [CrossRef]

151. Chen, F.H.; Yu, Z.C.; Yang, M.L.; Ito, E.; Wang, S.M.; Madsen, D.B.; Huang, X.Z.; Zhao, Y.; Sato, T.; Birks, H.J.B.; et al. Holocene moisture evolution in arid central Asia and its out-of-phase relationship with Asian monsoon history. Quat. Sci. Rev. 2008, 27, 351-364. [CrossRef]

152. Kutzbach, J.E. Monsoon climate of the early Holocene: Climate experiment using the earth's orbital parameters for 9000 years ago. Science 1981, 214, 59-61. [CrossRef]

153. Koutavas, A.; deMenocal, P.B.; Olive, G.C.; Lynch-Stieglitz, J. Mid-Holocene El Niño-Southern Oscillation (ENSO) attenuation revealed by individual foraminifera in eastern tropical Pacific sediments. Geology 2006, 34, 993-996. [CrossRef] 
154. Yancheva, G.; Nowaczyk, N.R.; Mingram, J.; Dulski, P.; Schettler, G.; Negendank, J.F.W.; Liu, J.Q.; Sigman, D.M.; Peterson, L.C.; Haug, G.H. Influence of the intertropical convergence zone on the East Asian monsoon. Nature 2007, 445, 74-77. [CrossRef]

155. Berger, A.; Loutre, M.F. Insolation values for the climate of the last 10 million years. Quat. Sci. Rev. 1991, 10, 297-317. [CrossRef]

156. Chen, F.H.; Jia, J.; Chen, J.H.; Li, G.Q.; Zhang, X.J.; Xie, H.C.; Xie, D.S.; Huang, W.; An, C.B. A persistent Holocene wetting trend in arid central Asia, with wettest conditions in the late Holocene, revealed by multi-proxy analyses of loess-paleosol sequences in Xinjiang, China. Quat. Sci. Rev. 2016, 146, 134-146. [CrossRef]

157. An, Z.S.; Colman, S.M.; Zhou, W.J.; Li, X.Q.; Brown, E.T.; Jull, A.J.T.; Cai, Y.J.; Huang, Y.S.; Lu, X.F.; Chang, H.; et al. Interplay between the Westerlies and Asian monsoon recorded in Lake Qinghai sediments since $32 \mathrm{ka}$. Sci. Rep. 2012, 2, 619. [CrossRef] [PubMed]

158. Bohner, J. General climatic controls and top climatic variations in central and high Asia. Boreas 2006, 35, 279-295. [CrossRef]

159. Vandenberghe, J.; Renssen, H.; van Huissteden, K.; Nugteren, G.; Konert, M.; Lu, H.Y.; Dodonov, A.; Buylaert, J.P. Penetration of Atlantic westerly winds into central and East Asia. Quat. Sci. Rev. 2006, 25, 2380-2389. [CrossRef]

160. Li, D.L.; Shao, P.C.; Wang, H.; Chen, L. Advances in Research of the North boundary belt of East Asia subtropical Summer Monsoon in China. Plateau Meteorol. 2013, 32, 305-314. (In Chinese)

161. Zhou, W.J.; Yu, S.Y.; Georges, B.; Kukla, G.J.; Jull, A.J.T.; Xian, F.; Xiao, J.Y.; Colman, S.M.; Yu, H.G.; Liu, Z.; et al. Postglacial changes in the Asian summer monsoon system: A pollen record from the eastern margin of the Tibetan Plateau. Boreas 2010, 39, 528-539. [CrossRef]

162. Chen, M.; Pollard, D.; Barron, E.J. Regional climate change in East Asia simulated by an interactive atmosphere-soil-vegetation model. J. Clim. 2004, 17, 557-572. [CrossRef]

163. Kuper, R.; Kröpelin, S. Climate-controlled Holocene occupation in the Sahara: Motor of Africa's evolution. Science 2006, 313, 803-807. [CrossRef]

164. Jia, X.; Yi, S.W.; Sun, Y.G.; Wu, S.Y.; Lee, H.F.; Wang, L.; Lu, H.Y. Spatial and temporal variations in prehistoric human settlement and their influencing factors on the south bank of the Xar Moron River, Northeastern China. Front. Earth Sci. 2016, 11, 137-147. [CrossRef]

165. Liu, L.; Chen, X.C.; Wright, H.; Xu, H.; Li, Y.Q.; Chen, G.L.; Zhao, H.T.; Kim, H.; Lee, G. Rise and fall of complex societies in the Yiluo region, North China: The spatial and temporal changes. Quat. Int. 2019, 521, 4-15. [CrossRef]

166. Zhang, X.L.; Wang, J.X.; Xian, Z.Q.; Qiu, S.H. Studies on ancient human diet. Archaeology 2003, 2, $62-75$. (In Chinese)

167. Sun, Y.G.; Zhao, Z.J. A comprehensive study on plant remains excavated from Weijiawopu site, a Hongshan site. Agric. Archaeol. 2013, 33, 1-5. (In Chinese)

168. Jin, G.; Luan, F.; Zhang, C.; Wang, Y. Liaodong bandao nanbu nongye kaogu diaocha baogao-Zhiguiti de zhengju. Dongfang Kaogu 2009, 6, 306-316. (In Chinese)

169. Rosen, A.M.; Macphail, R.; Liu, L.; Chen, X.; Weisskop, A. Rising Social Complexity, Agricultural Intensification, and the Earliest Rice Paddies on the Loess Plateau of Northern China. Quat. Int. 2015, 437, 50-59. [CrossRef]

170. Costin, C.L. Craft specialization: Issues in defining, documenting, and explaining the organization of production. Archaeol. Method Theory 1991, 5, 1-56.

171. Zhang, H.; Bevan, A.; Guo, D.S. The neolithic ceremonial complex at Niuheliang and wider Hongshan landscapes in Northeastern China. J. World Prehistory 2013, 26, 1-24. [CrossRef]

172. Drennan, R.D.; Peterson, C.E.; Lu, X.M.; Li, T. Hongshan households and communities in Neolithic northeastern China. J. Anthropol. Archaeol. 2017, 47, 50-71. [CrossRef]

173. Lee, G.-A.; Crawford, G.W.; Liu, L.; Chen, X. Plants and people from the early Neolithic to Shang periods in North China. Proc. Natl. Acad. Sci. USA 2007, 104, 1087-1092. [CrossRef]

174. Sun, G.Q. "Henan jingnei de Dawenkou wenhua he Qujialing wenhua" (The Dawenkou Culture and Qujialing Culture in Henan). Zhongyuan Wemvu 2000, 2, 22-28. (In Chinese)

175. Li, X.Q.; Shang, X.; Dodson, J.; Zhou, X.Y. Holocene agriculture in the Guanzhong Basin in NW China indicated by pollen and charcoal evidence. Holocene 2009, 19, 1213-1220. [CrossRef] 
176. Wei, J. Miaozigou and Dabagou the Report on Excavation of Ancient Sites of Primitive Inhabitant Tribes in the New Stone Age; Encyclopedia of China Publishing House: Beijing, China, 2003. (In Chinese)

177. Mo, D.W.; Yang, X.Y.; Wang, H.; Li, S.C.; Guo, D.S.; Zhu, D. Study on the Environmental background of Niuheliang site, Hongshan culture, and the relationship between ancient man and environment. Quat. Sci. 2002, 22, 174-181. (In Chinese)

178. Zhang, J.X.; Wang, X.Y.; Yang, R.X.; Li, X.Z.; Zhang, W. Multicultural responses to environmental changes of the Holocene in the Nihewan-Huliu Basin of North China. Quat. Int. 2019, 507, 53-61.

179. Zhou, X.Y.; Li, X.Q.; Zhao, K.L.; Dodson, J.; Sun, N.; Yang, Q. Early agricultural development and environmental effects in the Neolithic Longdong basin (eastern Gansu). Chin. Sci. Bull. 2011, 56, 762-771. [CrossRef]

180. Cui, Y.F.; Liu, Y.J.; Ma, M.M. Spatiotemporal evolution of prehistoric Neolithic-Bronze Age settlements and influencing factors in the Guanting Basin, northeast Tibetan Plateau. Sci. China (Earth Sci.) 2018, 61, 149-162. [CrossRef]

181. Chen, F.H.; Dong, G.H.; Zhang, D.J.; Liu, X.Y.; Jia, X.; An, C.B.; Ma, M.M.; Xie, Y.W.; Barton, L.; Ren, X.Y.; et al. Agriculture facilitated permanent human occupation of the Tibetan Plateau after 3600 BP. Science 2015, 347, 248-250. [CrossRef] [PubMed]

182. Lu, L.D. Mid-Holocene Climate and Cultural Dynamics in Eastern Central China; Climate and Cultural Change: Exploring Holocene Transitions; Academic Press: Salt Lake City, UT, USA, 2007; pp. 279-330.

(C) 2019 by the authors. Licensee MDPI, Basel, Switzerland. This article is an open access article distributed under the terms and conditions of the Creative Commons Attribution (CC BY) license (http://creativecommons.org/licenses/by/4.0/). 